\title{
An integrated open-coastal biogeochemistry, ecosystem and biodiversity observatory of the eastern Mediterranean - the Cretan Sea component of the POSEIDON system
}

\author{
George Petihakis ${ }^{1}$, Leonidas Perivoliotis ${ }^{1}$, Gerasimos Korres ${ }^{1}$, Dionysios Ballas ${ }^{1}$, Constantin Frangoulis ${ }^{1}$, \\ Paris Pagonis $^{1}$, Manolis Ntoumas ${ }^{1}$, Manos Pettas ${ }^{1}$, Antonis Chalkiopoulos ${ }^{1}$, Maria Sotiropoulou ${ }^{1}$, Margarita Bekiari ${ }^{1}$, \\ Alkiviadis Kalampokis ${ }^{1}$, Michalis Ravdas ${ }^{1}$, Evi Bourma ${ }^{1}$, Sylvia Christodoulaki ${ }^{1}$, Anna Zacharioudaki ${ }^{1}$, \\ Dimitris Kassis $^{1}$, Emmanuel Potiris ${ }^{1, a}$, George Triantafyllou ${ }^{1}$, Kostas Tsiaras ${ }^{1}$, Evangelia Krasakopoulou ${ }^{1, a}$, \\ Spyros Velanas ${ }^{1}$, and Nikos Zisis ${ }^{1}$ \\ ${ }^{1}$ Institute of Oceanography, Hellenic Centre for Marine Research (HCMR), 72100 Heraklion, Greece \\ apresent address: Department of Marine Sciences, School of the Environment, \\ University of the Aegean, 81132 Mytilene, Greece
}

Correspondence: Constantin Frangoulis (cfrangoulis@ hcmr.gr)

Received: 18 January 2018 - Discussion started: 6 February 2018

Revised: 6 August 2018 - Accepted: 30 August 2018 - Published: 12 October 2018

\begin{abstract}
There is a general scarcity of oceanic observations that concurrently examine air-sea interactions, coastal-openocean processes and physical-biogeochemical processes, in appropriate spatiotemporal scales and under continuous, long-term data acquisition schemes. In the Mediterranean Sea, the resulting knowledge gaps and observing challenges increase due to its oligotrophic character, especially in the eastern part of the basin. The oligotrophic open Cretan Sea's biogeochemistry is considered to be representative of a greater Mediterranean area up to $10^{6} \mathrm{~km}^{2}$, and understanding its features may be useful on even larger oceanic scales, since the Mediterranean Sea has been considered a miniature model of the global ocean. The spatiotemporal coverage of biogeochemical (BGC) observations in the Cretan Sea has progressively increased over the last decades, especially since the creation of the POSEIDON observing system, which has adopted a multiplatform, multivariable approach, supporting BGC data acquisition. The current POSEIDON system's status includes open and coastal sea fixed platforms, a Ferrybox (FB) system and Bio-Argo autonomous floats that remotely deliver fluorescence as a proxy of chlorophyll$a(\mathrm{Chl}-a), \mathrm{O}_{2}, \mathrm{pH}$ and $p \mathrm{CO}_{2}$ data, as well as BGC-related physical variables. Since 2010, the list has been further expanded to other BGC (nutrients, vertical particulate matter fluxes), ecosystem and biodiversity (from viruses up to zooplankton) variables, thanks to the addition of sediment traps,
\end{abstract}

frequent research vessel $(\mathrm{R} / \mathrm{V})$ visits for seawater-plankton sampling and an acoustic Doppler current profiler (ADCP) delivering information on macrozooplankton-micronekton vertical migration (in the epipelagic to mesopelagic layer). Gliders and drifters are the new (currently under integration to the existing system) platforms, supporting BGC monitoring. Land-based facilities, such as data centres, technical support infrastructure, calibration laboratory and mesocosms, support and give added value to the observatory. The data gathered from these platforms are used to improve the quality of the BGC-ecosystem model predictions, which have recently incorporated atmospheric nutrient deposition processes and assimilation of satellite Chl- $a$ data. Besides addressing open scientific questions at regional and international levels, examples of which are presented, the observatory provides user-oriented services to marine policy makers and the society, and is a technological test bed for new and/or cost-efficient BGC sensor technology and marine equipment. It is part of European and international observing programs, playing a key role in regional data handling and participating in harmonization and best practices procedures. Future expansion plans consider the evolving scientific and society priorities, balanced with sustainable management. 


\section{International need for observatories}

Oceans are complex dynamic systems embracing various physical, chemical and biological processes interacting on a wide range of timescales and space scales. The increasing anthropogenic pressures add another layer of complexity to their study. Ocean observatories are long-term infrastructure dedicated to multiple in situ observations (from air-sea interface to the bottom ocean and the water column), which are maintained over long timescales, with adequate temporal resolution, and are designed to address interdisciplinary objectives over wide spatiotemporal scales. The observatory concept created by scientific needs is driven today by societal needs to understand the connections between ocean processes and society (Ruhl et al., 2011), with the necessity for continued long-term ocean observation also recognized politically by the international community by the United Nations Conference on Sustainable Development at Rio + 20 (Cicin-Sain et al., 2011). At the European level, the coordinating bodies (European Marine Board - EMB; European Global Ocean Observing System - EuroGOOS) of the European observatories, besides addressing specific scientific questions, come also to address Europe's societal and policy demands for sustainable use of the seas, ecosystem-based management and establishment of environmental status indicators, as expressed by the EU's Marine Strategy Framework Directive (MSFD).

Biogeochemical-ecosystem research is a key component in ocean observatories. The International GeosphereBiosphere Programme (IGBP) (led by the Intergovernmental Oceanographic Commission - IOC of UNESCO), since its first projects (JGOFS - Joint Global Ocean Flux Study), as well as with its current ones (IMBER - Integrated Marine Biosphere Research), has realized that key biogeochemical variables and ecosystems must also be systematically and long-term observed, in order to study marine biogeochemical cycles and their interactions with the ecosystems, at the seasonal and decadal scales, as well as in shortterm episodic events (http://www.imber.info, last access: 26 September 2018).

Biogeochemical-ecosystem long-term data are, however, available only from few locations worldwide (Karl, 2010) and scarcity increases when considering only open (deep) ocean observatories (Ruhl et al., 2011). The European Marine Board (EMB) has published a position paper on critical challenges of deep-sea research, stressing that a current limitation of observatories is that they mainly monitor almost exclusively abiotic variables (Rogers et al., 2015).

\section{A strategic location to study the unknowns of the eastern Mediterranean}

The Mediterranean Sea also "suffers" from this scarcity of observatories, especially with an open-ocean component.
Although long-term time series of physical, chemical and plankton ecosystem variables exist in several shallow (< $200 \mathrm{~m}$ ) coastal sites ( $<10$ nautical miles offshore) (e.g. Goffredo and Dubinsky, 2014), few offshore and deep ocean (> $1000 \mathrm{~m}$ ) biogeochemical observatories exist in the Mediterranean (Ruhl et al., 2011; http://www.eurosites.info, last access: 10 January 2018). This leaves several questions for its physical and biogeochemical status unanswered, including, among others, processes occurring in intermediate and deep layers, variability of the stock of nutrients, biological pump functioning, mesopelagic community structure and multiple stressor impact on ecosystem functioning (Malanotte-Rizzoli et al., 2014).

In the open eastern Mediterranean Sea, numerous studies of biogeochemical processes have been focused on various spatial scales (large scale to mesoscale); however, these studies were seasonal and only two covered an annual cycle (Cretan Sea, Tselepides and Polychronaki, 2000; Cilician Basin, Eker-Develi et al., 2006).

The Cretan Sea biogeochemical-ecosystem observatory presented here comes to fill the above gap. This observatory is located in the most voluminous and deep $(2500 \mathrm{~m})$ basin of the Aegean Sea, giving the opportunity to study not only properties limited to the specific area but also the characteristics of the open eastern Mediterranean basin. In fact, the open Cretan Sea's biogeochemistry has been estimated to represent an area in the eastern Mediterranean varying from 0.6 to $1.6 \times 10^{6} \mathrm{~km}^{2}$ (Fig. 1) depending on the biogeochemical variable (see variables in Henson et al., 2016). Understanding the Cretan Sea's features may be useful on larger oceanic scales, since the Mediterranean Sea has been considered a "miniature ocean" that can be used as a model to anticipate the response of the global ocean to various kinds of pressures (Bethoux et al., 1999). These Cretan Sea features, presented below, underline the strategic location of the observatory.

\subsection{Coupling of biogeochemistry with circulation patterns}

The Cretan Sea plays an important role in the dynamics of the eastern Mediterranean circulation and has been considered as a heat, salt and dissolved oxygen reservoir with high temperature $\left(>14{ }^{\circ} \mathrm{C}\right)$ and salinity $(>38.9)$ in its intermediate and deep layers. It is also the poorer in nutrients and richer in oxygen $\left(>4.3 \mathrm{~mL} \mathrm{~L}^{-1}\right)$, among the principal basins of the Mediterranean Sea (e.g. Souvermezoglou and Krasakopoulou, 2000; http://www.mongoos.eu/data-center, last access: 26 September 2018).

The Cretan Sea is an area of intermediate and/or deepwater formation, dominated by multiple scale circulation patterns and intense mesoscale variability (e.g. Georgopoulos et al., 2000). Such areas of water formation are key locations for monitoring of the Mediterranean biogeochemical functioning (Malanotte-Rizzoli et al., 2014). 


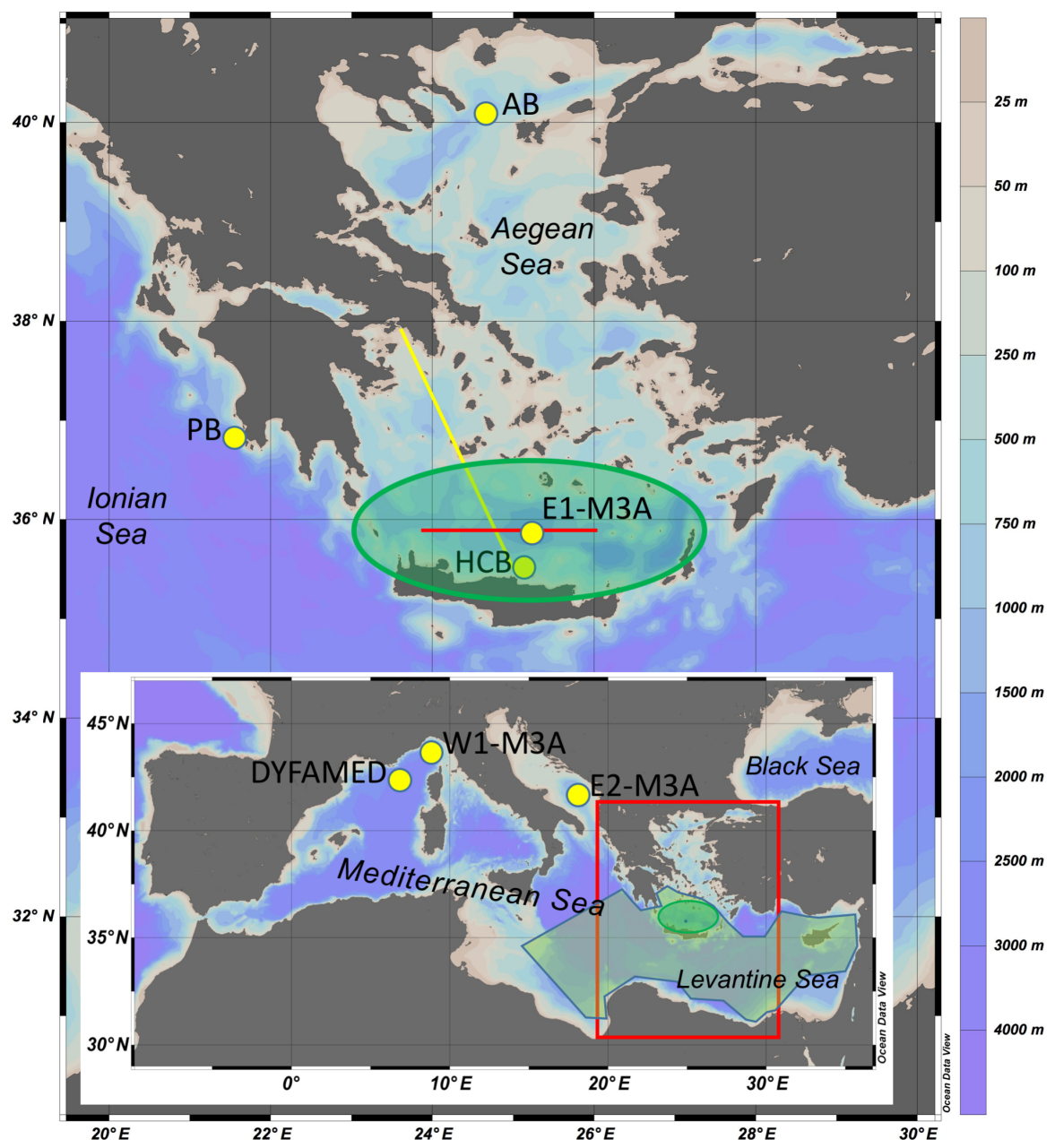

Figure 1. Map of showing the location of the Cretan Sea (green ellipse) and all POSEIDON system physical-biogeochemical fixed platforms (yellow dots; see Sect. 4.1), glider endurance line (red line; see Sect. 4.5) and Ferrybox (yellow line; see Sect. 4.3). Inset map shows the location within the Mediterranean Sea (red square), location of other biogeochemical (BGC) fixed platforms (from http://www.oceansites.org, last access: 26 September 2018) and E1-M3A spatial footprint (green area) for Chl- $a$ using satellite observations (redrawn after Henson et al., 2016). The E1-M3A location includes, in addition to the BGC fixed platform, an acoustic Doppler current profiler (ADCP) and sediment traps.

In the late 1980s to early 1990 s, the Cretan Sea became the major contributor of deep/bottom, warmer, more saline water to the eastern Mediterranean (review by Laskaratos et al., 1999 and references therein; Theocharis et al., 2014). This transition, known as the eastern Mediterranean transient (EMT), dramatically altered the physical and biogeochemical properties at the intermediate and deep layers of the whole basin (Roether et al., 2007, among others). Data collected from different platforms in the Cretan Sea during the 2000s present evidence of gradually increasing salinity in the intermediate and deep intermediate layers after the middle of the decade. From the late 2000s to early 2010s, dense water formation conditions have been identified, showing that the basin is slowly returning to the state of the late pre-EMT period (Velaoras et al., 2014; Cardin et al., 2015).
The deep-water mass formation in the Cretan Sea has the potential to transfer $\mathrm{CO}_{2}$ into the deep layers. However, there is a sparseness of carbonate system data, i.e. total inorganic carbon $\left(C_{\mathrm{T}}\right)$, total alkalinity $\left(A_{\mathrm{T}}\right), \mathrm{pH}$ and $p \mathrm{CO}_{2}$ in the wider eastern Mediterranean, to understand its role as source or sink of $\mathrm{CO}_{2}$ (González-Dávila et al., 2016; Sisma-Ventura et al., 2016), and the existing $A_{\mathrm{T}}-S$ relationships for the Mediterranean do not reproduce efficiently the $A_{\mathrm{T}}$ levels observed in the Aegean Sea (Krasakopoulou et al., 2015).

The significant variability in the circulation patterns (e.g. Korres et al., 2014) and the strong coupling with the biogeochemical processes in the Cretan Sea (Tselepides and Polychronaki, 2000) has made evident that sparse spatial and temporal observations are prone to misrepresentation of the underlying dynamics. 


\subsection{Oligotrophy, primary production, plankton stock and biodiversity hot spots}

The eastern Mediterranean basin (including the Cretan Sea) is considered to be an ultra-oligotrophic system, in terms of both Chl- $a$ concentration (D'Ortenzio and Ribera d'Alcalà, 2009) and primary productivity (Siokou-Frangou et al., 2010 and references therein). The dominance of the multivorous food web in the Cretan Sea (Siokou-Frangou et al., 2002) is a dissimilarity with most areas of the Mediterranean Sea where the microbial food web generally dominates (SiokouFrangou et al., 2010 and references therein).

The Mediterranean Sea also constitutes a hot spot of biodiversity with a uniquely high percentage of endemic species (Coll et al., 2010 and references therein). However, biodiversity studies are still limited in the Mediterranean both for benthos (Danovaro et al., 2010) and plankton (SiokouFrangou et al., 2010). In addition, the eastern Mediterranean is more subject to change by the invasion of alien species in combination with warming (Coll et al., 2010). All the above factors make clear the interest of studying the biodiversity of the open Cretan Sea.

\subsection{Mid- and deep-water biological pump efficiency}

The inhabitants of the deep sea play an important role in determining the depths to which carbon is exported, a role mainly played by microbes and zooplankton (review by Turner, 2015). The lack of data from mid-water depths severely limits our ability to quantify the efficiency of the biological pump (Robinson et al., 2010). In the eastern part of Mediterranean, less is known on deep living zooplankton (review by Saiz et al., 2014).

In the Cretan Sea, deep-water mesozooplankton have occasionally been studied (Siokou et al., 2013) and the vertical flux of zooplankton faecal pellets quantified (Wassman et al., 2000). In this area, macrozooplankton vertical migration appears to occur at diel and seasonal scale down to $500 \mathrm{~m}$ (Potiris et al., 2018). Since zooplankton vertical migration may constitute an important active vertical flux increasing the biological pump's efficiency (review by Frangoulis et al., 2005), its role in the Cretan Sea pump needs exploration.

\subsection{Basin to global anthropogenic impact}

Although it is clear that human activities have modified the biogeochemical cycles of nutrients (Galloway et al., 2008), the understanding of the marine ecosystems' response to these variations is limited. The eastern Mediterranean is characterized by an anomalous $\mathrm{N}: \mathrm{P}$ ratio ranging from 25 to 28 , significantly higher than the normal oceanic Redfield ratio (16:1) (Kress, 2003). In this basin, atmospheric deposition is believed to be the main source of nutrients in the euphotic zone of the open sea, other than the vertical mixing of water during winter (Christodoulaki et al., 2013 and ref- erences therein), but the exact contribution to the balance of nutrients and the resulting impact on the productivity remain uncertain (Duce et al., 2008).

Under global warming, a stronger stratification of the water column (Barale et al., 2008) could increase the importance of the external sources of nutrients like atmospheric deposition. However, thermal instability in the atmosphere could lead to strong convective events in the atmosphere that could also increase the vertical mixing in the water column, bringing up nutrients (Christodoulaki et al., 2016).

Besides atmospheric deposition, a large part of the Mediterranean coasts host areas with coastal water contamination occurring by pollutants (EEA, 2006) and changes in the quality and quantity of river inputs (Ludwig et al., 2009). The Cretan Sea, according to its river discharges, is qualified as having open-ocean characteristics (Ludwig et al., 2009 and references therein). However, river discharge only does not allow to fully support the assumption that this area receives only basin- to global-scale anthropogenic impact. In fact, it has still to be verified against other poorly known open-ocean anthropogenic activities in this area, such as fisheries (including deep ecosystems exploitation), maritime transport and noise.

\section{Aims and mission}

The Cretan Sea observatory is the most biogeochemistryecosystem-oriented multiplatform subsystem of POSEIDON. POSEIDON (http://www.poseidon.hcmr.gr, last access: 26 September 2018) is an observatory research infrastructure of the eastern Mediterranean basin, for the monitoring and forecasting of the marine environment, supporting the efforts of the international and local community and replying to the needs and gaps of science, technology and society (Perivoliotis et al., 2018). It was developed in three phases under the funding of EEA Financial Mechanism $(85 \%)$ and Greek national funds (15\%): POSEIDONI (1997-2000), a first-generation buoy monitoring network with operational centre, forecasting system and relevant human resources; POSEIDON-II (2005-2008), a system upgrade and expansion; and finally, POSEIDON-III (20092011), a deep sea observing capacity expansion. During the period from 2011 to 2017, there were no major upgrades and the system was partly supported by EU and national projects. In 2017, an extended upgrade and renewal of POSEIDON buoy network monitoring parts and components and their supporting hardware was realized with the implementation of an integrated marine monitoring program funded by the EEA Financial Mechanism (2009-2014). POSEIDON's biogeochemical-ecosystem observational component aims, mainly achieved via its most oriented biogeochemicalecosystem-oriented subsystem of the Cretan Sea, are presented below. 
(A) The scientific objectives coming out from the international (Ruhl et al., 2011; IMBER, 2005, 2010; NRC, 2011), European (EGMRI, 2013) as well as national scientific projects, are to provide scientific knowledge and support on the study of

a. ocean "mechanisms", including their interactions and spatiotemporal variability (duration, occurrence, matches and mismatches) - the currently examined mechanisms are solubility and biological pump, transformation and transfer of matter (fluxes within food webs and in and out of ocean interfaces) and oceanatmosphere interactions (heat, dust, $\mathrm{CO}_{2}$ );

b. "food web structure" (stock, functional groups, microbial loop, size spectra) and "biodiversity" related variables (number of species present and their temporal variability), in order to help understand species interaction with food web functioning and biogeochemical cycling; and

c. the sensitivity of biodiversity and the variability of ocean mechanisms in relation to combined "natural forcing factors and anthropogenic pressures". The current pressures considered are those induced by warming (temperature, circulation, stratification, wind mixing, extreme-episodic events), ocean acidification (carbonate chemistry), nutrient dynamics (stoichiometry, dust deposition) and oxygen concentration. Other pressures and feedback effects planned to be considered in the future studies of the observatory are presented in Sect. 8.

(B) The management aims based on the experience acquired by POSEIDON team and international management recommendations (NRC, 2011; Karl, 2010; Ruhl et al., 2011) are as follows:

a. "sustainability" through prioritization and cost-effective management (this aim guides the expansion of the number and of the spatiotemporal coverage of the variables studied; see Sect. 7);

b. "integration" of disciplines, platforms and analysis methods, by bridging various measurement scales and methodologies as well as through a step-by-step integration of an increasing number of different biogeochemical platforms (see Sect. 4), variables and analysis methods (see Sect. 5);

c. maintenance of a "quality controlled biogeochemicalecosystem database", with reduced data delivery time and expanded accessibility (see Sect. 6);

d. support of "ecosystem model" validation for improved ecosystem forecasting and management;

e. provision of a "technology test bed" for new biogeochemical sensors; and f. maintenance of "collaboration through strong networking with similar observatories" for common strategy, complementary tasks, protocol standardization and transfer of knowledge (see Sect. 4).

(C) The third goal is to provide services to marine policy makers and the society, while adaptation to the evolving needs is ensured by a feedback mechanism put in place. POSEIDON is being developed in accordance to the policy framework suggested by IOC/GOOS, EuroGOOS, the Mediterranean Operational Network for the Global Ocean Observing System (MonGOOS) and the Group on Earth Observations (GEO). The achievement of these objectives is made through collaboration with scientists from other disciplines including social scientists, and in communication with policy makers and the wider public. Within this framework the observatory aims to

a. provide policy makers with sound scientific knowledge to assist in making informed decisions - the observatory provides several MSFD descriptors (D1: biological diversity, D2: commercial fish, D3: food web, D4: hydrological conditions) and tests indicators of ecosystem health status;

b. promote understanding of anthropogenic impact on the ocean systems and at the same time the dependence on them; and

c. provide products to the end user through the POSEIDON operational biogeochemistry and ecosystem modelling tools.

A balance between the operational and research character of the infrastructure is maintained through the integration of methodologies and tools developed in relevant EU initiatives and projects. In parallel, the objectives are adapted based on new science and society goals and future scopes are considered in the strategic plan (see Sect. 8).

\section{Platforms and components}

The present (2018) status of the Cretan Sea's coastal openocean biogeochemistry, ecosystem and biodiversity observatory includes (a) an open sea fixed platform with a multisensor array, (b) a coastal fixed platform with a multi-sensor array, (c) open sea sediment traps, (d) an open sea acoustic Doppler current profiler (ADCP) (e) open sea sampling through regular R/V visits, (f) coastal sampling through regular R/V visits, (g) a Ferrybox (FB) and (h) a glider (Figs. 1 and 2). It is complemented by land-based Hellenic Centre for Marine Research (HCMR) facilities (laboratories, mesocosms, calibration room) located on the island of Crete. The Cretan Sea observatory platforms are integrated within a wider area network of Eulerian and Lagrangian (Bio-Argo floats) biogeochemical (BGC) platforms. Remote sensing 
(satellite) and BGC-ecosystem modelling products are used for the validation of measurements, and vice versa. Last, but not least, comes the experienced multitasking personnel with significant experience in all aspects of the system.

We describe below these components via a historical evolution describing the progressive introduction of several platforms operating in the long term, and their development towards a more biogeochemical-ecosystem orientation.

\subsection{Fixed platforms - from physics to biogeochemistry and to zooplankton vertical migration}

In the framework of EuroGOOS, a multi-national effort to develop an integrated operational monitoring and forecasting system for the Mediterranean Sea took place under the Mediterranean Forecasting System (MFS) project (Pinardi and Flemming, 1998). During the pilot phase of the project (1998-2001), a significant element of the designed observing systems was the Mediterranean Moored Multi-sensor Array (M3A) deployed in the open Cretan Sea, a prototype observatory that was designed to form the basis of a permanent network of moored stations for continuous recording of open-ocean conditions in the Mediterranean Sea (Nittis et al., 2003). From the eight planned stations in the Mediterranean, the E1-M3A was the prototype, the first open-ocean buoy deployed in the Mediterranean in January 2000, followed by two other M3A stations in the southern Adriatic (E2) and Ligurian Sea (W1) a few years later (Fig. 1).

The present-day-named POSEIDON E1-M3A buoy (WMO 61277) is the founder component of the Cretan Sea observatory. The current configuration was designed and built during the second phase of POSEIDON. The mooring is located about 24 nautical miles north of the island of Crete at a depth of $1400 \mathrm{~m}$ (Figs. 1 and 3) and is currently the most developed physical-biogeochemical observing site of the POSEIDON system (Petihakis et al., 2007). Biogeochemical sensors currently deployed on the buoy are $\mathrm{O}_{2}$, fluorescence (Chl- $a$ ), $p \mathrm{CO}_{2}$ and $\mathrm{pH}$ (described in detail in Sect. 5). It is considered a reference point for monitoring open-ocean biogeochemical processes (including air-sea interactions) of the eastern Mediterranean and part of the operational oceanography observing system developments supporting the MSFD implementation in the Mediterranean Sea (Bozzano et al., 2013). Consolidating on the long experience of physical variables monitoring, the objective of the observatory has been expanded to include regular monitoring of the epipelagic ecosystem and the associated biogeochemistry (see Sect. 4.2).

Next to the E1-M3A buoy location, a fixed position ADCP was first deployed in 2000 for a period of 1 year. This $75 \mathrm{kHz}$ ADCP, placed at $600 \mathrm{~m}$ looking upward, allowed to study currents at multiple depths and gave indication of the presence of vertical migration of scatterers, probably large zooplankton (Cardin et al., 2003). Acknowledging the impor- tance of this particular mechanism in the modulation of the ecosystem, in 2012, the ADCP was redeployed (depth $500 \mathrm{~m}$ ), and it provided data to analyse the vertical migration patterns (at diel and seasonal scale) of large zooplankton from $400 \mathrm{~m}$ to the surface (Fig. 7; Potiris et al., 2018).

In 2016, the Cretan Sea observatory was expanded with a second fixed platform, the Heraklion coastal buoy (HCB) (Figs. 1 and 3). This Oceanor Seawatch buoy, coupled with the existing infrastructure (open sea buoy, Ferrybox, $\mathrm{R} / \mathrm{V}$ missions, Bio-Argos) in the area, opens possibilities to study the interaction of coastal with open sea processes (e.g. wave dynamics, exchanges of matter, extreme events spatial extend). Since 2017, two more POSEIDON buoys outside the Cretan Sea have also provided biogeochemical data $\left(\mathrm{O}_{2}, \mathrm{Chl}-a\right)$. Similar to E1-M3A, these two Oceanor Wavescan buoys are deployed in the north Aegean and Ionian waters. The buoy placed between the Athos peninsula and the island of Lemnos (AB) (Fig. 1) monitors an area affected (e.g. with increased productivity) by the Black Sea water entering the north Aegean through the Dardanelles straits, which plays a significant role modulating the thermohaline characteristics and dynamics of the whole Aegean Sea, including the Cretan Sea (e.g. Korres et al., 2014). The Pylos site (PB) in the southeast Ionian is a crossroad where intermediate and deep-water masses meet. The site is located on the pathway of the Aegean Sea dense water that travels to the north along the western coast of Greece. These three buoys (E1-M3A, AB and PB) providing meteorological, physical and biogeochemical data in different areas have allowed comparison of trends of physical variables (such as the temporal increasing trend in temperature; see Fig. 4) and may allow the future comparison of biogeochemical variables in different levels of oligotrophy.

\subsection{Water column sampling and sediment traps ( $R / V$ cruises) - from occasional high spatial resolution snapshots to sustained temporal coverage}

The biogeochemistry of the Cretan Sea has been studied approximately every 2 to 5 years since the 1980 s by in situ sampling using R/Vs in the framework of different research programs (e.g. POEM, PELAGOS, CINCS, MATER, SESAME, PELAGIAL). However, having a wide spatial coverage, most of the cruises were at the best made at seasonal scale (generally in mid-spring and early autumn). In addition, there was a large sampling gap between 1999 and 2005 (Fig. 5), while only from 1993 to 1995 , during the CINCS project, highfrequency (bi-monthly) sampling was performed (Danovaro and Serresi, 2000; Psarra et al., 2000; Tselepides and Polychronaki, 2000; Van Wambeke et al., 2000). Parallel to this, sediment traps were also deployed in the Cretan Sea during the CINCS project (1994-1995) (Stavrakakis et al., 2000) and MATTER project (1997-1998) (Lykousis et al., 2002). 


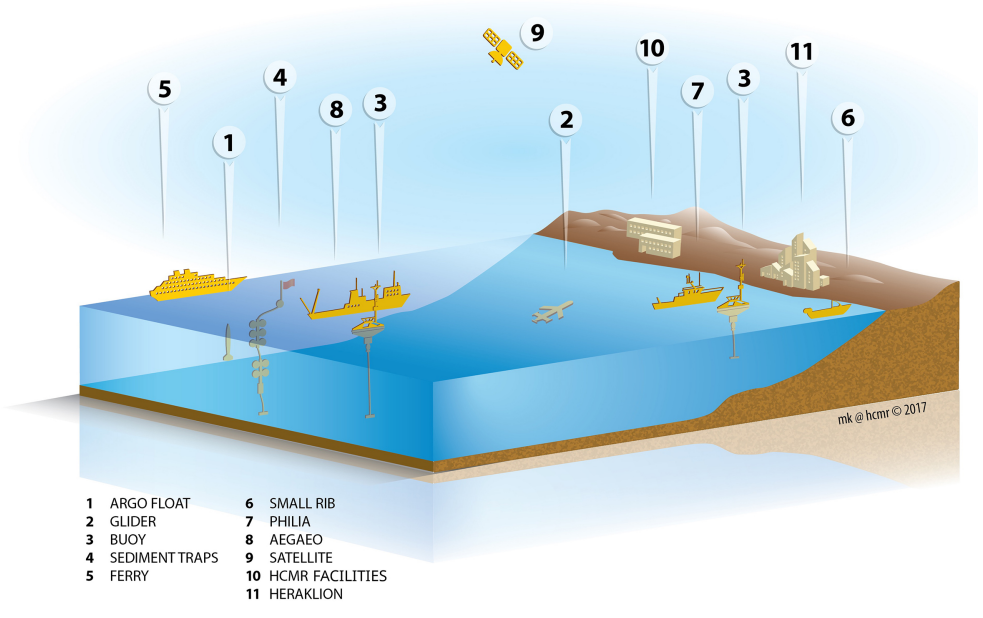

Figure 2. Platforms of the Cretan Sea biogeochemical-ecosystem observatory.

(a)

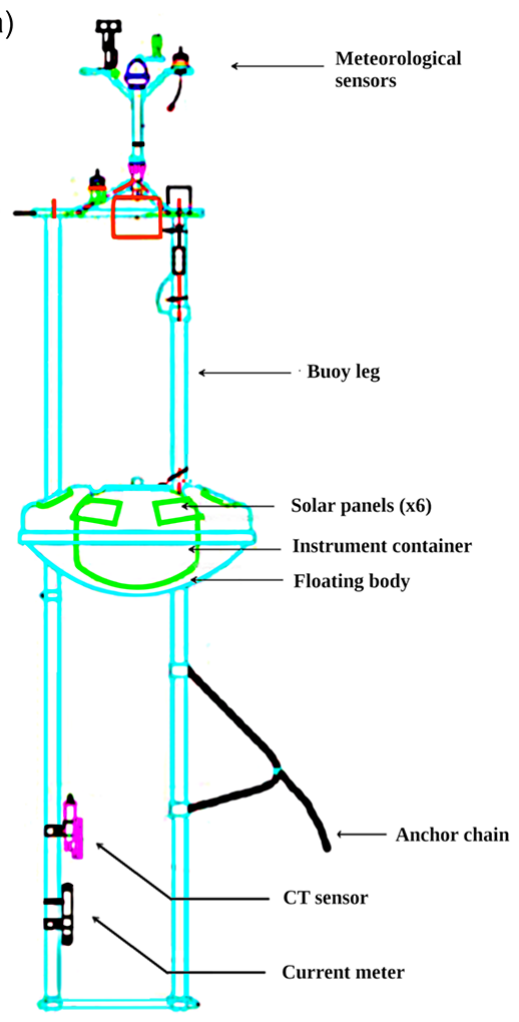

(b)

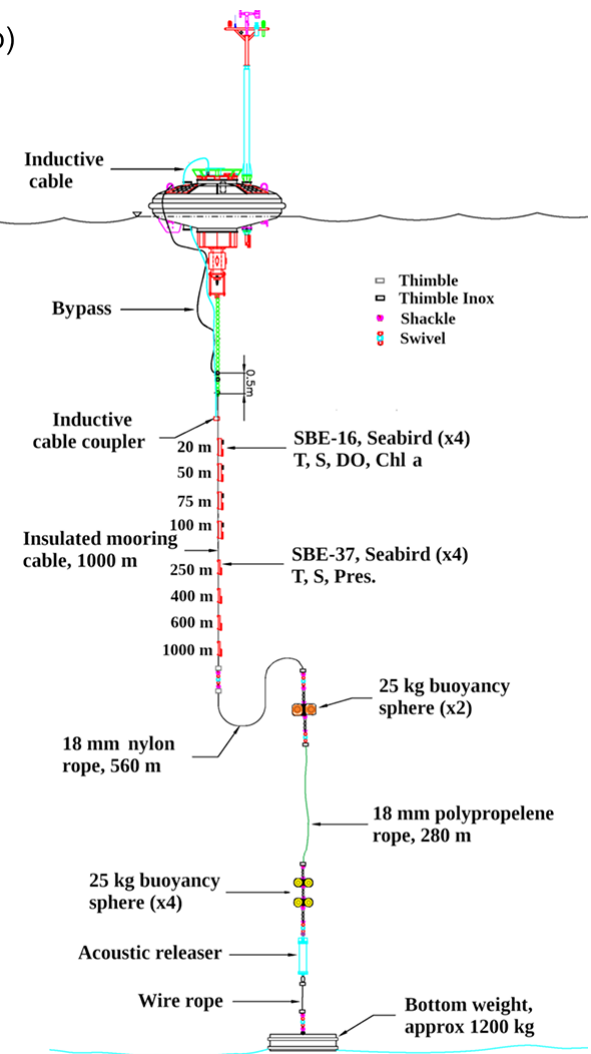

Figure 3. Coastal (a) and open sea (b) fixed platform configuration with a scheme of the payload.

A major contribution towards the implementation of longterm biogeochemical monitoring based on regular R/V visits was made in 2010, when the Institute of Oceanography of HCMR initiated a continuous sampling program at the POSEIDON E1-M3A site (Fig. 5). Initially it included conductivity-temperature-depth (CTD) casts and seawater/plankton sampling providing multiple variables (e.g. $T, S$ and Chl- $a$ shown in Fig. 6). Later on (2011), it was complemented with two sediment traps and a year later (2012) with an ADCP (see Sect. 4.1). Since 2016, CTD casts and seawater/plankton sampling have also been performed at monthly frequency next to the coastal fixed platform HCB. These initiatives are maintained until present (2018). 


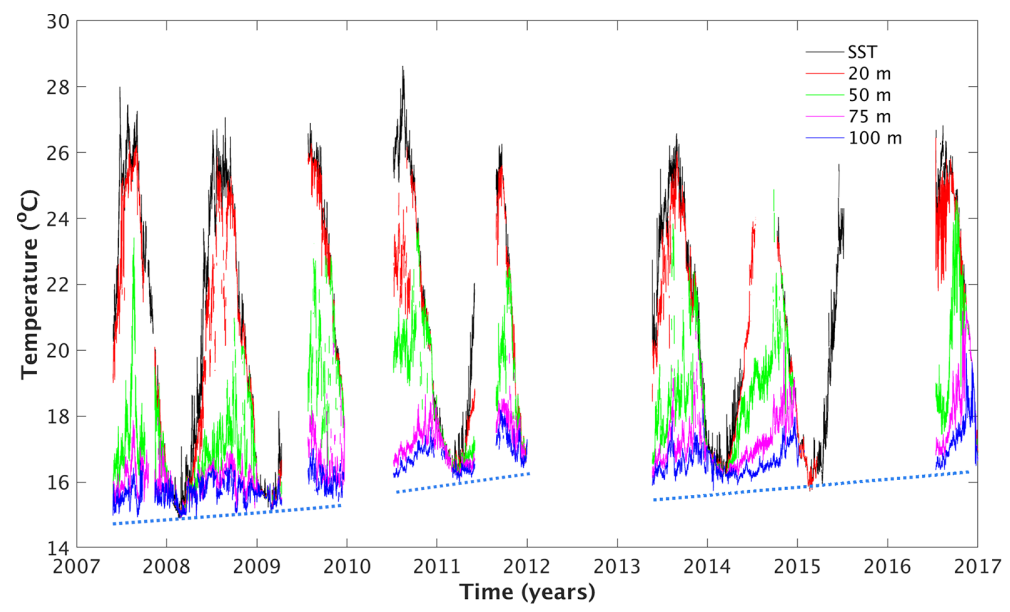

Figure 4. Temperature recordings at the E1-M3A buoy from 2007 to 2017.

\subsection{Ferrybox - from temperature and salinity to carbonate system}

A Ferrybox system operated for the first time in the Mediterranean, on the route connecting the ports of Piraeus (Athens) and Heraklion (Fig. 1), for 1 year between 2003 and 2004 within the framework of the EU-funded project Ferrybox. This fully automated, flow-through system included sensors for underway measurement of temperature, salinity, fluorescence and turbidity. High-frequency measurements took place every night, and the data were delivered in near-real time (NRT). The system was reactivated in 2012 for a few years until the end of 2014. Recently, since mid-2017, it has been running continuously with an upgrade to provide also $\mathrm{O}_{2}, \mathrm{CO}_{2}$ and $\mathrm{pH}$ measurements. The $\mathrm{FB}$ has been proven a helpful tool in the study of water circulation (e.g. modified Black Sea water flowing in the Aegean Sea), in particular when assimilated into prognostic numerical circulation models to improve their accuracy (Korres et al., 2014). For surface Chl- $a$ validation/calibration, a comparison of FB's fluorescence with satellite data as well as near-surface measurements of Chl- $a$ (by discrete water sampling) from nearby $\mathrm{R} / \mathrm{V}$ cruises is a powerful multi-tool. An example of a first comparison of FB and satellite data from 2017 depicts higher values by both platforms in the Saronikos Gulf (Fig. 8) and opens questions that need further investigation. First, the comparison denotes differences between the two platforms which could most probably be due to differences in the time of acquisition (nighttime FB versus daytime satellite means), the spatial acquisition (FB data from $3 \mathrm{~m}$ depth versus satellite sea-surface $1 \mathrm{~km}$ horizontal resolution data) and/or sensing-data processing method. In addition, it denotes differences within FB data acquired in the Saronikos Gulf, depending on the direction of the vessel (mainly related to sensor adaptation time after FB reinitialization).

\subsection{Bio-Argo floats}

During 2012, the Greek Argo infrastructure was launched as a component of the POSEIDON observing system, with the aim to purchase and deploy 25 ARGO floats (http://www. greekargo.gr, last access: 26 September 2018), further contributing to the international ARGO community efforts to monitor the eastern Mediterranean region. In 2016, five of the 15 Greek deployed floats were Bio-Argos (equipped with $\mathrm{O}_{2}$ sensor). It is worth noticing that in the Aegean Sea the ARGO recordings are largely based on POSEIDON floats.

\subsection{Gliders}

Two SeaExplorer gliders were added in 2017 to the monitoring platforms of the POSEIDON system. The two gliders will be gradually integrated to the operational network of the system with the ultimate objective of establishing at least two endurance lines in the Aegean and Ionian seas. In the Cretan Sea, the continuous monitoring that has started in late 2017 through an endurance line (example of first results shown in Fig. 9) is expected to contribute to the further knowledge of the seasonal variability of the flow field, collecting also evidence of the intermediate or deep-water formation events that are known to occur in the area.

The gliders' $T / S$ profiles, collected during a 6-month period, will be used in observing systems experiments (OSEs) to assess the impact of the continuous monitoring of the Cretan Sea on the hydrodynamic modelling of the Aegean Sea, as the former plays a significant role in water mass exchanges with the eastern Levantine basin, through the east and west Cretan straits. It is interesting to see that the seasurface height distribution as derived from satellite altimetry (Fig. 9a) is reasonably consistent with the vertical temperature and salinity structures depicted in Fig. $9 \mathrm{~b}$ and c. In fact, as the glider transverses from west to east, the elongated anticyclonic eddy structure located to the north of Crete at 


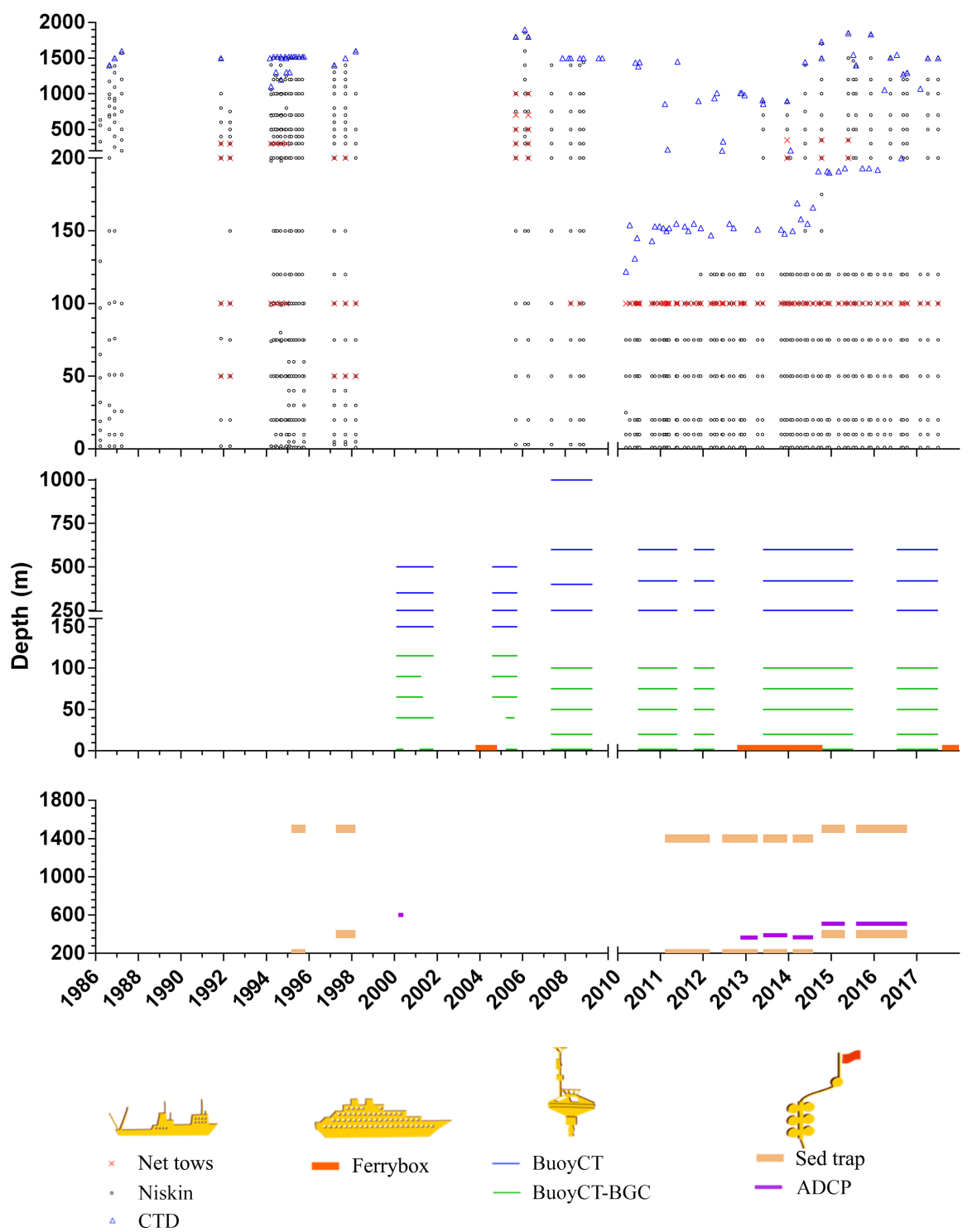

Figure 5. Periods of operation of the different platforms located in the open Cretan Sea (historical metadata within a circle of 20 nautical miles radius around the position of E1-M3A; exclusion of metadata made within 10 nautical miles from a coast). Before 2010, the metadata listed may not be exhaustive. Conductivity-temperature-depth (CTD) casts and net tows were made from the surface to the depth shown in the figure. Ferrybox entry point is located at $3 \mathrm{~m}$ depth. BGC: $\mathrm{O}_{2}$ and/or fluorescence sensors. CT: conductivity and temperature.

approximately $23.8-24.8^{\circ} \mathrm{E}$ (Fig. 9a) displays a noticeable deepening of the isothermals and isohalines, as revealed by the measured profiles, that goes down to $300 \mathrm{~m}$ depth. It is expected that the introduction of these glider measured profiles to the Aegean Sea dynamics, through data assimilation system, will act synergistically with the satellite altimetry trivially assimilated into the system.

\subsection{Biogeochemical modelling}

Forecasting tools are centrally placed in the POSEIDON system, with a number of state-of-the-art weather, wind waves, ocean circulation and marine ecosystem numerical models, initialization and data assimilation schemes providing information 5 days ahead on a daily basis regarding the atmospheric (Papadopoulos et al., 2002), sea state (Korres et., 2011) and hydrodynamic conditions (Korres et al., 2010) in the Aegean/Ionian seas and in the Mediterranean. Currently, the POSEIDON modelling group provides the wave forecasting products of the Copernicus Marine Environment Monitoring Service (CMEMS) for the Mediterranean Sea in the framework of MED-MFC.

The POSEIDON ecosystem simulation tool is one of the first developed in the Mediterranean, producing daily fore- 

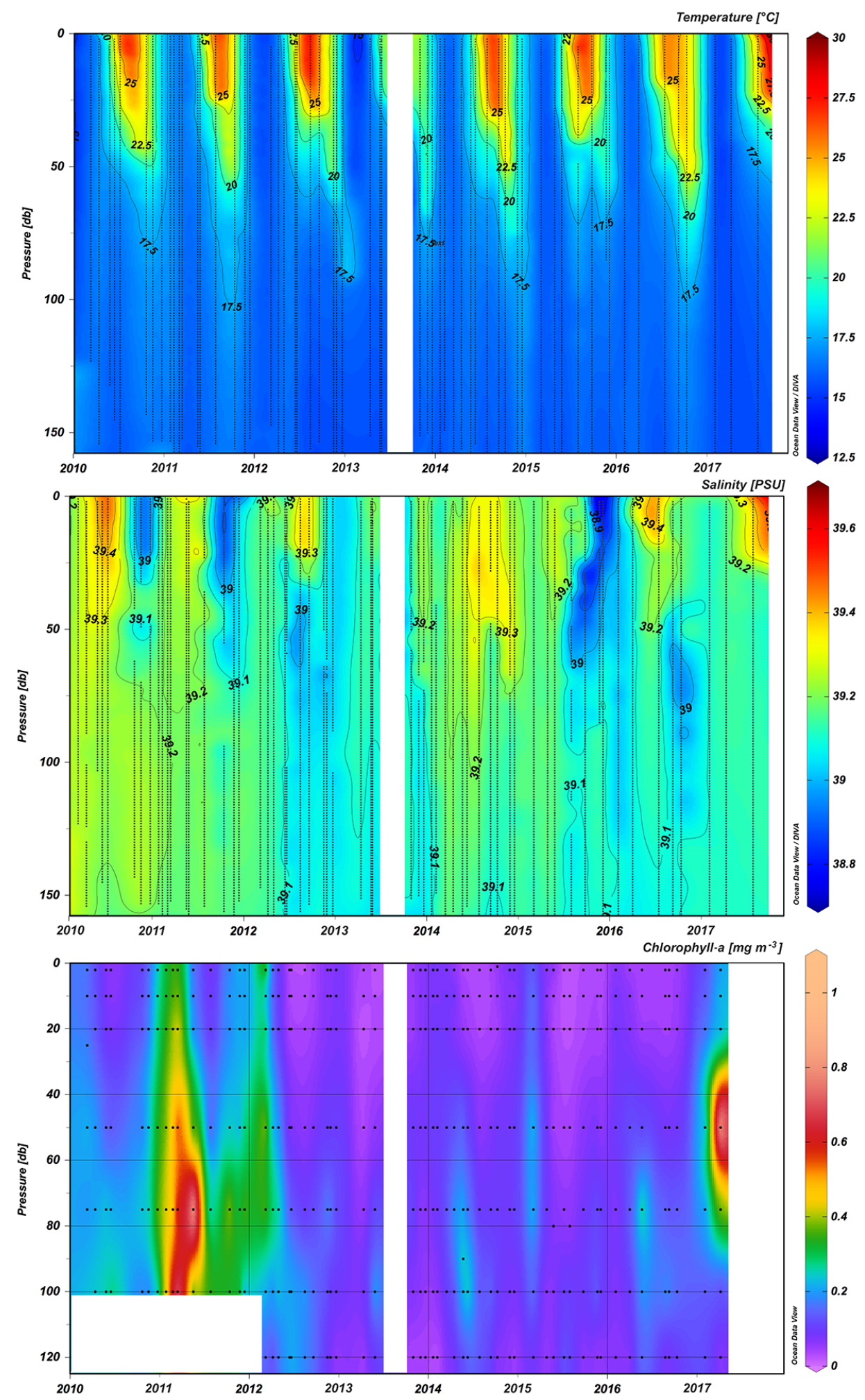

Figure 6. Vertical distribution of temperature, salinity (CTD casts) and total Chl- $a$ (fluorometric analysis of seawater from bottle sampling) from 2010 to 2017 at the POSEIDON E1-M3A location. 

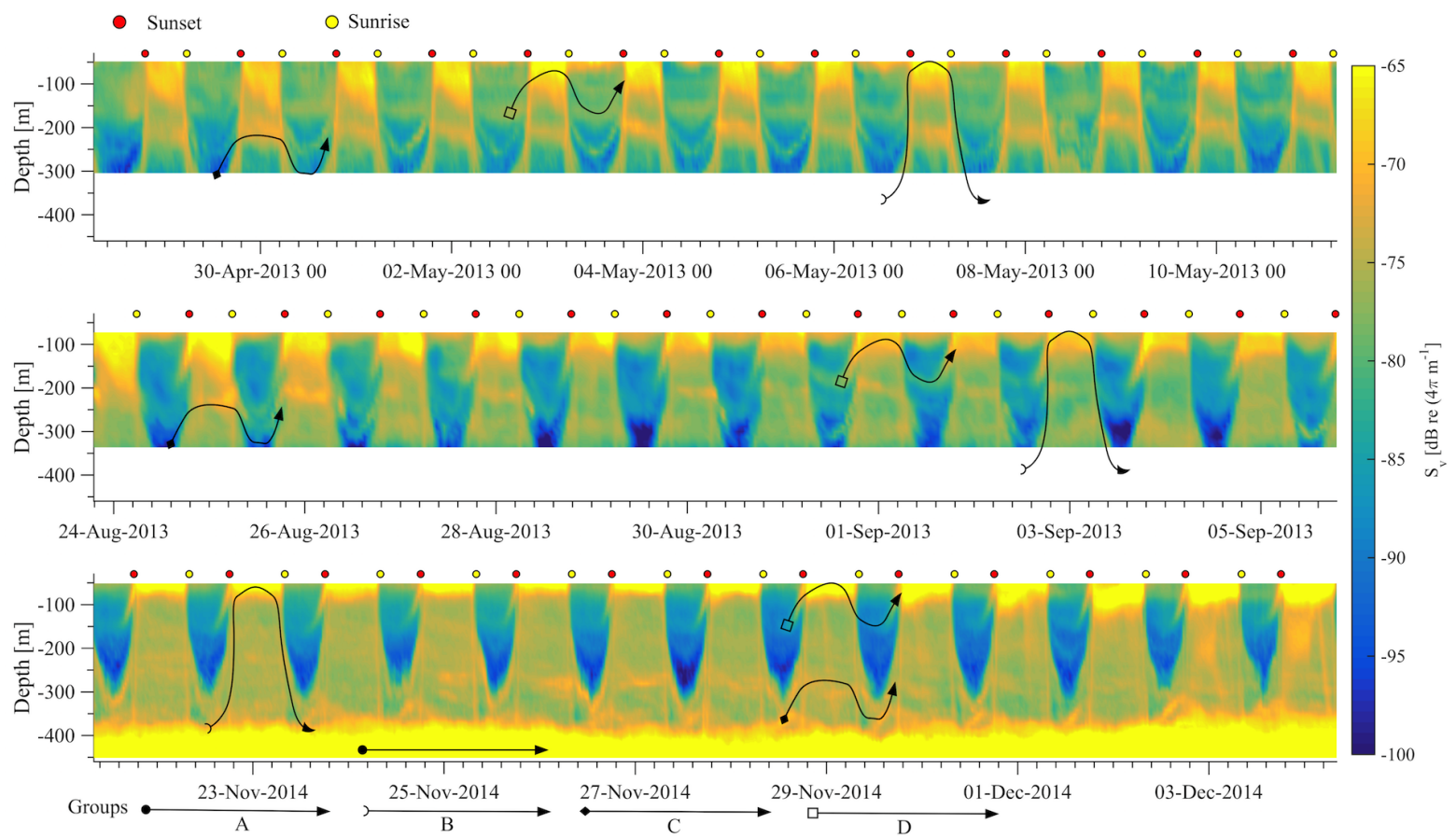

Figure 7. Backscatter coefficient Sv from the $75 \mathrm{kHz}$ ADCP placed at the POSEIDON E1-M3A location. Hand-drawn trails are attributed to different groups of zooplanktonic and micronectonic organisms (from Potiris et al., 2018).

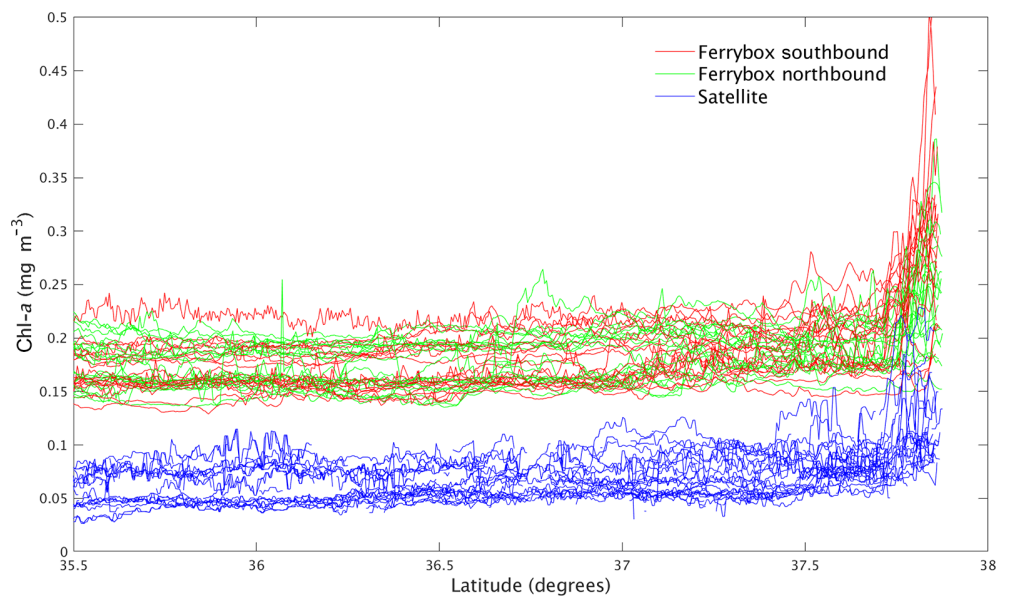

Figure 8. Comparison of POSEIDON Ferrybox's fluorescence data with satellite ocean colour data over a selected period (October 2017 to January 2018). FB data are separated depending on the direction of the vessel (green lines: southward towards Heraklion; red lines: northward towards Piraeus). Satellite data were obtained from the OCEANCOLOUR_MED_CHL_L3_REP_OBSERVATIONS_009_073 product available at http://marine.copernicus.eu/services-portfolio/access-to-products/ (last access: 26 September 2018).

casts for a range of ecosystem variables for the whole basin. The Cretan Sea has been a test site for the implementation of the biogeochemical European Regional Seas Ecosystem Model (ERSEM; Baretta-Bekker et al., 1995), since it is the only offshore site in Greece in which the ecosystem has been systematically observed, providing a very successful test bed for model development (Petihakis et al., 2002; Triantafyllou et al., 2003a, b, c; Hoteit et al., 2004). Data from POSEIDON buoys such as E1-M3A have been extensively used for model validation/calibration and testing of model parameterization techniques adopted in the operational POSEIDON models. Although the assimilation of these data directly in the model forecasts would have a relatively limited effect, given their small spatial coverage, they are of paramount importance for the development and testing of data assimilation schemes, as well as in the analysis of specific processes and the underly- 


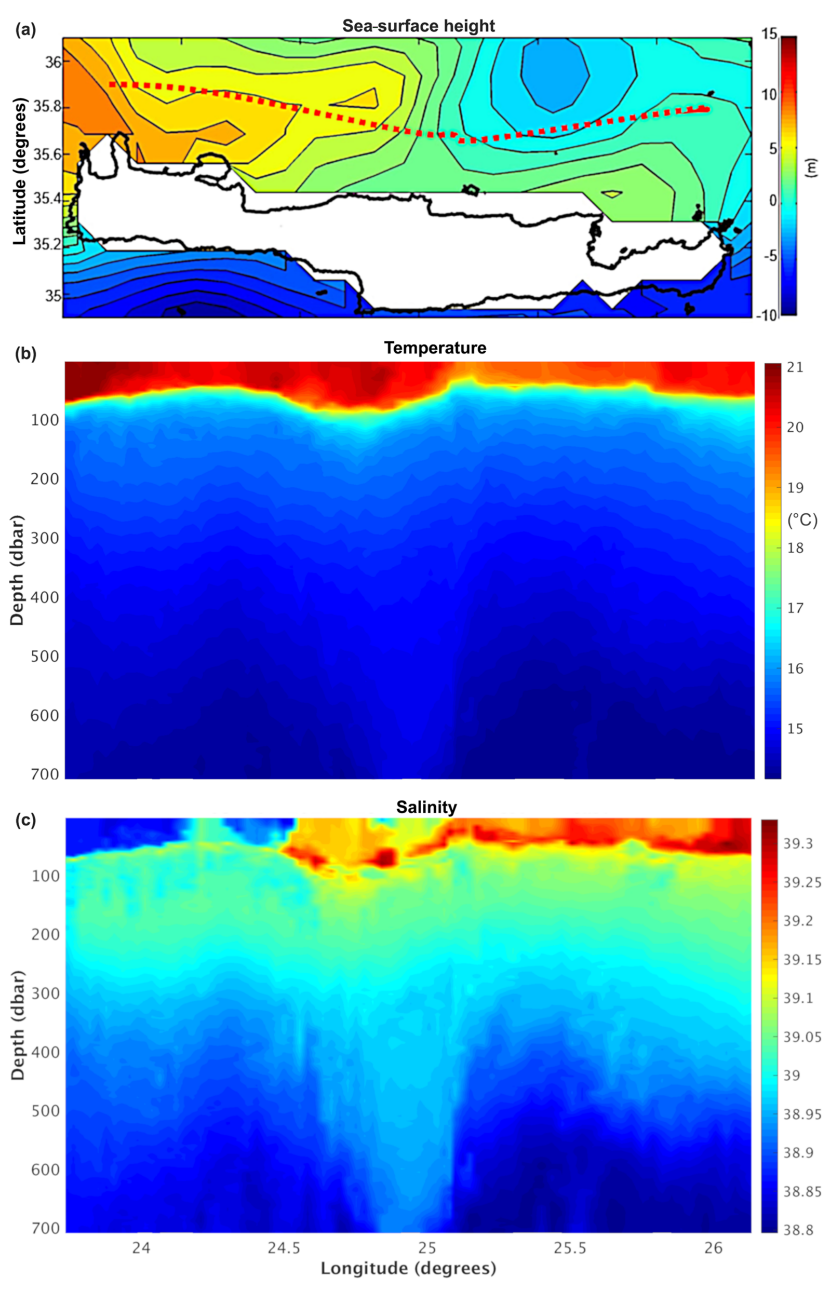

Figure 9. Sea-surface height (a) derived from satellite altimetry in the Cretan Sea in November 2017, in comparison to the vertical distribution of temperature (b) and salinity (c) obtained by the glider along a west-east transect (red dotted line in panel a).

ing dynamics of the system. General calibration-validation activities are applied to the operational models, as data from the observatory are used in conjunction with experiments (e.g. mesocosms; see Sect. 4.8) for the analysis and modelling of specific processes, such as the microbial functioning and the effect of the atmospheric deposition (Christodoulaki et al., 2013; Tsiaras et al., 2017), or for the assimilation algorithms of sea colour data in BGC models (Kalaroni et al., 2016).

\subsection{Personnel - from separate specialists to multitasking collaborators}

Specialized personnel is the main component for a smooth and continuous functioning of any multiplatform, multidisciplinary observatory. Since its beginning, POSEIDON invested in the necessary human resources, namely a dedicated group of scientists and engineers that operate, maintain and upgrade the system on a full-time basis. Over the last years, as the number and complexity of platforms significantly grew and as the inflow of data increased, the knowledge level of personnel became more demanding. Balancing these demands with personnel shortage, due to budgetary constraints, led not only technicians but also scientists to have multifunctional duties that "... may involve aspects of a bosun, chemical safety officer, satellite communications specialist, network administrator and electronics technicians" (NRC, 2011). In addition, despite the need for specialists of each domain remaining, it appeared necessary to share the basics in each domain among several persons (e.g. three having knowledge of buoy maintenance and deployment, five of seawater sampling, three of CTD cast data processing, etc.). Through active communication and with the support of various EU projects (JERICO, FixO3, JERICO-NEXT, EMSODEV, EMSOLINK), the personnel acquired precious experience by strong collaboration, continuous education and exchange of knowledge and experience with personnel of similar observatories.

\subsection{Land-based support facilities}

Sensor maintenance and analysis of discrete samples are not the only reasons for having several land-based facilities located near the observatory. Other land-based infrastructure, such as a calibration room, micro- and mesocosms, meteorological stations and an atmospheric deposition station, provide added value to the observatory.

The POSEIDON calibration lab (based in Heraklion) accommodates the regularly scheduled calibration of sensors, considering the local environmental conditions (e.g. for conductivity sensors, high salinity; for Chl- $a$, sensors low concentration and native phytoplankton species). The lab is equipped with a specially designed large calibration tank and several smaller fiberglass tanks. Several reference sensors and equipment allow calibration of temperature, conductivity, fluorescence (Chl- $a$ ), turbidity and dissolved oxygen sensors. It has been proved to be a powerful tool for the calibration of sensors deployed in the wider Mediterranean Sea (Pensieri et al., 2016). In particular, calibrations of fluorometers and turbidity sensors are especially important in the Mediterranean, and more so in the eastern part, since primary production is significantly lower compared to most other areas in the world where such sensors are operating (Bozzano et al., 2013).

Microcosm laboratory facilities allow performing experiments on the physiology of a specific species or group of organisms of the Cretan Sea. In addition, the land-based mesocosm facilities in Crete (http://www.aquacosm.eu/ mesocosm/cretacosmos/, last access: 26 September 2018), part of the MESOAQUA network of European mesocosm facilities, allow to better explore specific biogeochemical processes in connection with food web functioning occurring within the Cretan Sea oligotrophic ecosystem. 
Finally, the Finokalia atmospheric deposition monitoring site of the University of Crete located on the island of Crete (http://finokalia.chemistry.uoc.gr/, last access: 26 September 2018) is among the few atmospheric stations located along the coasts of the eastern Mediterranean, with the particularity of being a representative background station for atmospheric observations in the area (Kanakidou et al., 2011). The proximity of the Finokalia monitoring station with the Cretan Sea observatory offers a unique coupling of observing locations to study the impact of atmospheric deposition in the Mediterranean Sea (e.g. Kouvarakis et al., 2001).

\subsection{Connection with European and international observatories}

A regional observatory can reach a higher potential when it belongs to a wide network of observatories (Ruhl et al., 2011). Ocean observation at global scale is implemented through the international program GOOS (Global Ocean Observing System) executed by the Intergovernmental Oceanographic Commission (IOC) under the auspices of UNESCO (http://www.ioc-goos.org/, last access: 26 September 2018), aiming to inform scientists, policymakers and society (Karl, 2010). GOOS is a global network of ships, buoys (fixed and drifting), subsurface floats, tide gauges and satellites that collect real-time data on the physical state as well as the biogeochemical profile of the world's oceans for three critical themes: climate, ocean health and real-time services.

At the European level, the EMB and EuroGOOS (http: //eurogoos.eu/, last access: 26 September 2018) have joined forces towards a truly integrated and sustained European Ocean Observing System (EOOS) as suggested by the Ostend Declaration (EurOCEAN 2010 conference) and described in the EMB position paper "Navigating the $\mathrm{Fu}$ ture IV" (EMB, 2013).

For the open ocean, the OceanSITES project, an integral part of GOOS, facilitates international coordination of time series at fixed locations (http://www.oceansites.org, last access: 26 September 2018). The E1-M3A buoy of the Cretan Sea observatory is part of the global network OceanSITES, via its European contribution (EuroSITES and former EMSO ERIC), which established integration between the fixed-point deep ocean observing systems around Europe. A strong and direct collaboration is established with scientists from observatories operating in the Mediterranean focusing on open-ocean biogeochemistry (DYFAMED, W1M3A and E2-M3A) (Fig. 1) as well on the atmospheric deposition monitoring (Finokalia). The open-ocean observatory of the Cretan Sea has been expanded with a multiplatform coastal component (including coastal buoy and Ferrybox) in the framework of the JERICO-NEXT project in an attempt to characterize the timing, intensity and fate of organic matter and the coupling of offshore processes with coastal processes.

\section{Biogeochemical-ecosystem variables}

The complexity of ocean environment has led the international scientific community (e.g. GOOS expert panels) to identify essential ocean variables based on their relevance, feasibility and cost effectiveness (http://www.goosocean.org, last access: 26 September 2018). For comparison and consistency, it is also crucial for local observing systems to be an integral part of a wider network of observatories. The choice of variables and protocols used at the Cretan Sea observatory aims to follow international relevance, best practices and intercomparable methodologies, and is evolving towards more simplified and cost-effective sensing/sampling/analysis. The Cretan Sea observatory's biogeochemical variables, associated platforms and their spatiotemporal coverage are summarized in Fig. 10 and detailed in Sect. 5.1 and 5.2.

\subsection{Biogeochemical sensors}

Table 1 presents the BGC and associated variables measured by sensors on the various platforms of POSEIDON. The operation protocol for these sensors follows international best practices for standardized methods, regarding checking and maintaining sensor accuracy, on-demand manufacturer calibration, regular lab calibrations (Coppola et al., 2016) and comparisons with relevant in situ data. Sensors are replaced approximately every 10 years. Predeployment lab calibrations for dissolved oxygen (DO), turbidity and Chl- $a$ (fluorescence) sensors are performed in the POSEIDON calibration lab (described in Sect. 4.8). In situ comparisons ("field calibrations") are made for DO, $\mathrm{pH}$ and Chl- $a$ (fluorescence) sensors, by comparison with casts made with a reference CTD (regularly calibrated) and with discrete samples taken at the depth of deployment of the sensors.

\subsection{Adaptations of biogeochemical sampling and analytical (lab) methodology}

Seawater and plankton samples are taken regularly in the vicinity of the fixed biogeochemical platforms and aboard the FB. In addition, samples of sinking particulate matter are collected with sediment traps. The variables studied and the lab methods used for analysing these samples are summarized in Tables 2 and 3 .

Water-plankton sampling is made using either (a) a large (62 m) or medium (23 m) R/V, or (b) a small R/V (RIB boat). The small R/V offers the opportunity of maintaining long time series at a lower cost, is easier to schedule and is twice as fast as the larger vessels (thus allowing quick storage and analysis of samples at the land facilities). Overall, experience acquired up to now showed the small $\mathrm{R} / \mathrm{V}$ to be the most frequently used vessel. HCMR has therefore invested to build up its capabilities (e.g. new winch allowing casts much deeper than 1000 m; Fig. 11). 


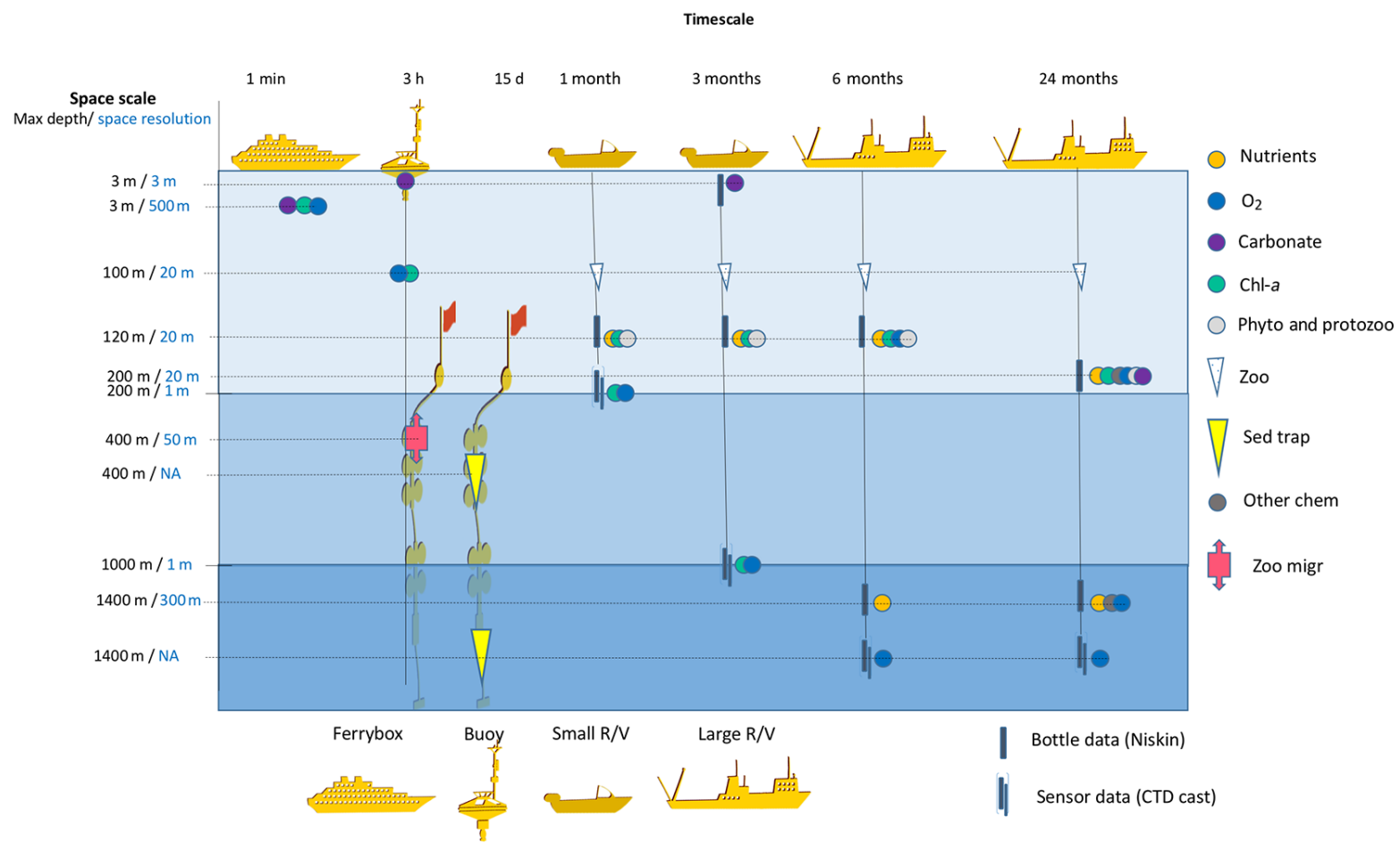

Figure 10. Time and space resolution of biogeochemical data acquisition by the different platforms of the observatory. The list of variables can be found in Tables 1-3. Space resolution is vertical except in the case of Ferrybox. Carbonate: $\mathrm{pH}, p \mathrm{CO}_{2}$ or $C_{\mathrm{T}}$ and $A_{\mathrm{T}}$; other chem: other chemical variables; sed trap: sediment trap; phyto and protozoo: phytoplankton and protozoans; zoo: metazoans (collected with nets); zoo migr: ADCP backscatter data for zooplankton migration.
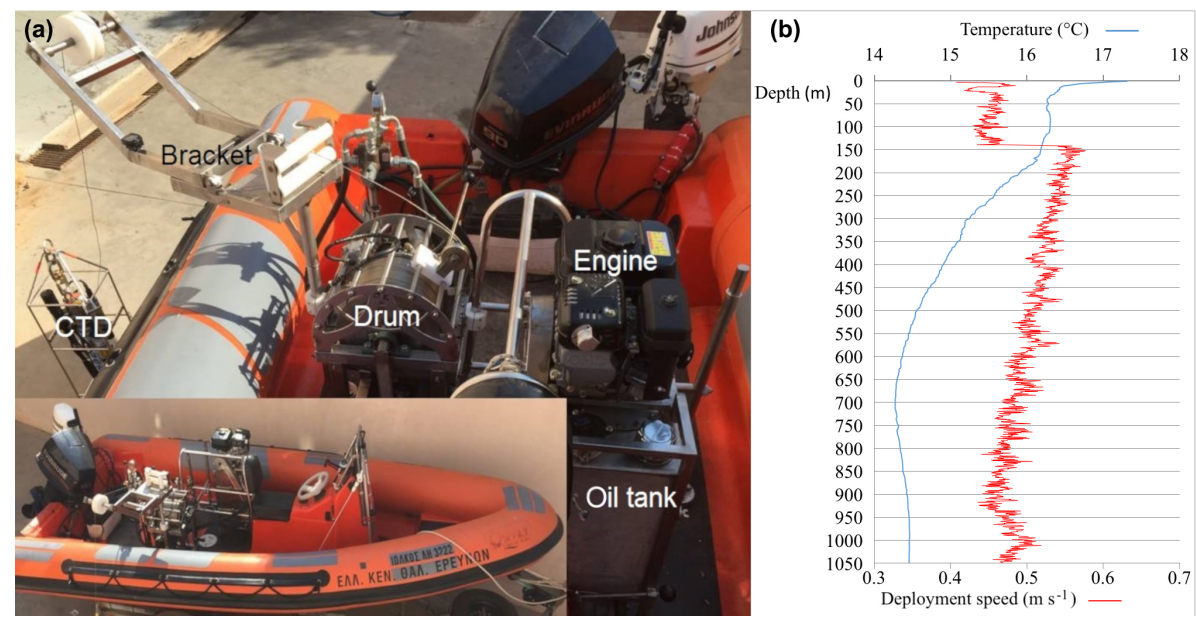

Figure 11. (a) Hydraulic winch positioned on a small RIB allowing casts $>1000 \mathrm{~m}$ (Pettas et al., 2015); (b) temperature and deployment speed against depth from a CTD cast made using the hydraulic winch. Deployment speed decrease above $150 \mathrm{~m}$ was made in order for the CTD to respond better to rapid environment changes like thermocline.

During the $\mathrm{R} / \mathrm{V}$ visits in the area of the fixed biogeochemical platforms, the order of sampling is always CTD and Niskin bottle casts followed by net tows. The vast majority of casts and net tows (>80\% after 2010) were made between 09:00 and 14:00 LT (local time). The or- der of sampling, the sampling procedure and storing protocols follow the international recommendations described by Lorenzoni and Benway (2013) and have remained consistent since 2010, with recording of cruise metadata (cruise summary reports are available at http://www.seadatanet.org, last 
(a)

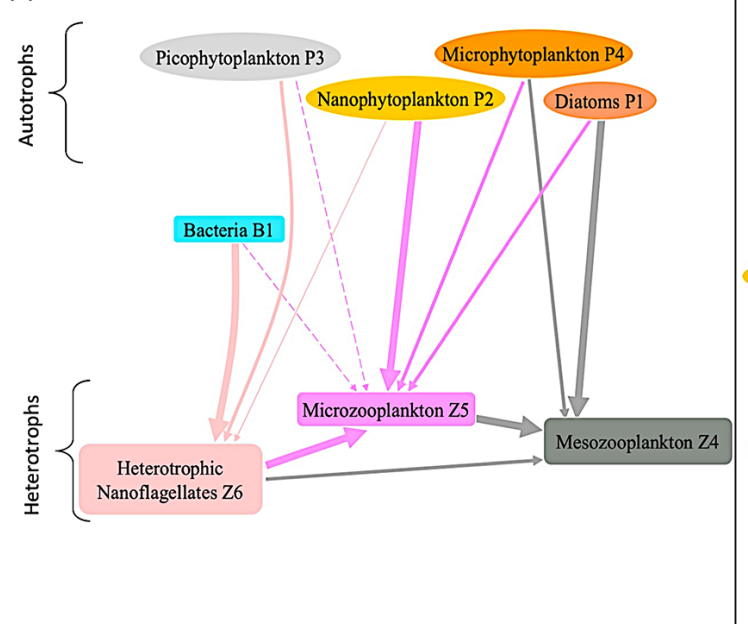

(b)

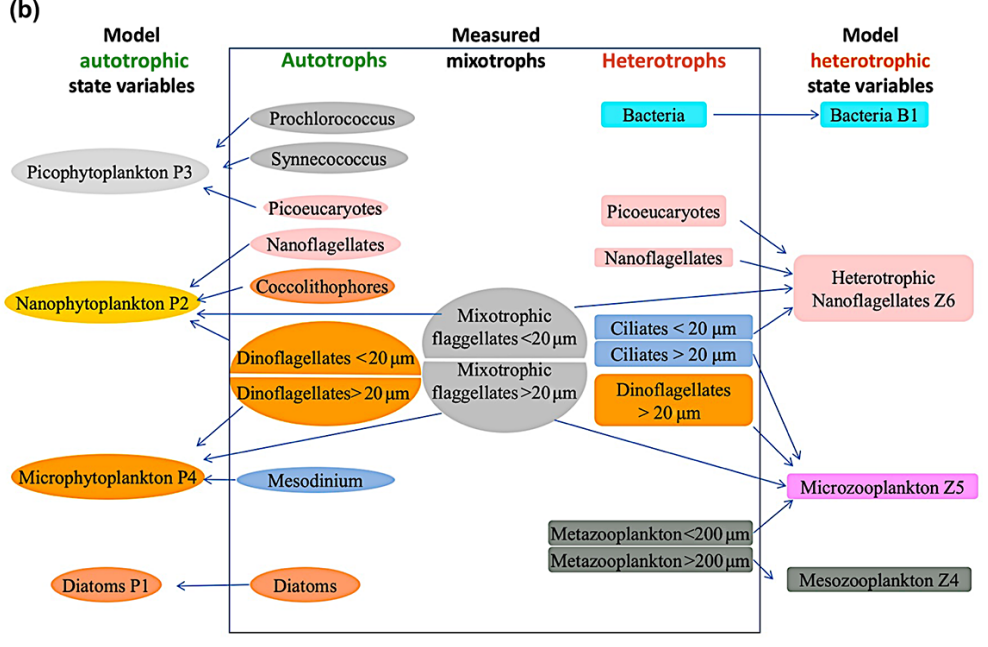

Figure 12. ERSEM model's food web structure (a) and correspondence between model variables and measured variables at the Cretan Sea observatory (b).

access: 26 September 2018). Adaptations of certain protocols have been made in certain cases, considering the openocean oligotrophic conditions of the area. For example, zooplankton sampling was initially made with a single $200 \mu \mathrm{m}$ mesh size net but soon it was changed into parallel two mesh size nets $(45 \mu \mathrm{m}$ mesh size and $200 \mu \mathrm{m}$ mesh size) tows. This was done due to the small size organisms found in the area, since combined data from several nets allow for a better estimation of the mesozooplankton biomass (Frangoulis et al., 2016). In all cases, when a new method was introduced, a minimum 1-year period of sampling and analysis using both old and new methods was applied, before moving exclusively to the new method (e.g. Chl- $a$ by fluorescence and by highperformance liquid chromatography (HPLC) were measured in parallel during 3 consecutive years).

\subsection{Derived biogeochemical-ecosystem variables and model state variables}

Any necessary unit conversion of physical and chemical oceanographic data for model validation is generally straightforward. However, many biological variables expressed in biomass units are usually derived from the initial data with some conversion factor assumed. These conversions introduce biases that have to be carefully considered by biologists and modellers (Flynn, 2005; Frangoulis et al., 2010; Tsiaras et al., 2017). In the case of the Cretan Sea biogeochemical-ecosystem model, the choice of appropriate conversion factors from literature, that can be considered, is made by the data providers (biologists) in communication with modellers and is revised regularly.

Besides units' conversion, provider-modeller communication is mandatory as the numerous measured biological variables often have no direct correspondence with the state vari- ables of the operational biogeochemical model. Figure 12 summarizes the correspondence between measured variables and ERSEM model variables used by the POSEIDON team for the Cretan Sea. Most plankton groups measured (except bacteria and diatoms) do not have a direct correspondence with a model variable. To make such links, several measured plankton groups have to be combined (e.g. Prochlorococcus, Synechococcus, picoeukaryotes), whereas others have to be split into subgroups based on their size (e.g. dinoflagellates $>$ 20 and $<20 \mu \mathrm{m}$ ) and/or trophic functioning (e.g. autotrophic and heterotrophic nanoflagellates). Mixotrophs field data were the most particular case, since they were split in four subgroups, creating an autotrophic and a heterotrophic subgroup to express mixotrophy (not represented in the model), which were subdivided again based on cell size (>20 and $<20 \mu \mathrm{m}$ ). A model application using such field data grouping/splitting for validation can be found in Tsiaras et al. (2017). Planktonologists and the modellers of the observatory agreed that there is no rule of thumb, and modelfield data correspondences should be adjusted according to the season and region.

\section{Metadata and data handling}

The POSEIDON database is set to include BGC and BGCassociated variables, either remotely sensed $\left(\mathrm{pH}, p \mathrm{CO}_{2}\right.$, Chl$a, \mathrm{O}_{2}$, meteorological, $T, S$ ) or obtained from in situ sampling (Chl- $a, \mathrm{O}_{2}$, nutrients, plankton stock). The processing and the quality control procedures for the data collected from all the POSEIDON stations comply with the Copernicus Marine Environment Monitoring Service (CMEMS) In Situ Thematic Assembly Center (INS TAC) procedures, as HCMR is the regional data distribution node for the Mediterranean Sea. A number of quality control procedures for the 
Table 1. Current status of marine BGC and associated variables $(T, S)$ measured from sensors in the POSEIDON platforms.

\begin{tabular}{|c|c|c|c|c|}
\hline Variable & Platform & Sensor & $\begin{array}{l}\text { Sensor } \\
\text { accuracy/ } \\
\text { sensitivity }\end{array}$ & $\begin{array}{l}\text { Frequency of } \\
\text { measurements }\end{array}$ \\
\hline \multirow[t]{4}{*}{$\begin{array}{l}\text { Temperature/ } \\
\text { salinity }\end{array}$} & $\begin{array}{l}\text { Buoys } \\
\text { (E1-M3A, HCB, AB, PB) }\end{array}$ & $\begin{array}{l}\text { SBE 16plus-IMP C-T-P } \\
\text { SBE } 37 \text { IM C-T }\end{array}$ & $\begin{array}{l} \pm 0.005^{\circ} \mathrm{C} / \\
\pm 0.0005 \mathrm{~S} \mathrm{~m}^{-1}\end{array}$ & $180 \mathrm{~min}$ \\
\hline & Ferrybox & Thermosalinometer SBE 45 & $\begin{array}{l} \pm 0.005^{\circ} \mathrm{C} / \\
\pm 0.0005 \mathrm{~S} \mathrm{~m}^{-1}\end{array}$ & $1 \mathrm{~min}$ \\
\hline & R/V (CTD) & SBE 19+ OR SBE 911 & $\begin{array}{l} \pm 0.005^{\circ} \mathrm{C} / \\
\pm 0.0005 \mathrm{~S} \mathrm{~m}^{-1}\end{array}$ & $1 \mathrm{~s}$ \\
\hline & Glider & $\begin{array}{l}\text { SBE GPCTD } \\
\text { (Glider Payload CTD) }\end{array}$ & $\begin{array}{l} \pm 0.002{ }^{\circ} \mathrm{Cl} \\
\pm 0.0003 \mathrm{~S} \mathrm{~m}^{-1}\end{array}$ & $30 \mathrm{~s}$ \\
\hline \multirow[t]{3}{*}{$\begin{array}{l}\text { Fluorescence } \\
(\text { Chl- } a)\end{array}$} & $\begin{array}{l}\text { Buoys } \\
(\text { E1-M3A, AB, PB) }\end{array}$ & WET Labs FLNTU & $0.025 \mu \mathrm{g} \mathrm{L}^{-1} \mathrm{Chl}$ & $180 \mathrm{~min}$ \\
\hline & Ferrybox & Scufa II Turner Design & $0.02 \mu \mathrm{g} \mathrm{L}^{-1} \mathrm{Chl}$ & $1 \mathrm{~min}$ \\
\hline & R/V (CTD) & $\begin{array}{l}\text { WET Labs ECO-AFL/FL } 9 \text { or } \\
\text { Chelsea Aqua } 3\end{array}$ & $0.025 \mu \mathrm{g} \mathrm{L}^{-1} \mathrm{Chl}$ & $1 \mathrm{~s}$ \\
\hline \multirow{7}{*}{$\begin{array}{l}\text { Dissolved } \\
\text { oxygen }\end{array}$} & Buoys & SBE 43/ & $\pm 2 \% /$ & $180 \mathrm{~min}$ \\
\hline & (E1-M3A, AB, PB) & SBE 63/ & $\pm 2 \% /$ & \\
\hline & & Aanderaa optode & $\pm 5 \%$ & \\
\hline & Ferrybox & Aanderaa optode & $\pm 5 \%$ & $1 \mathrm{~min}$ \\
\hline & Bio-Argos & Aanderaa optode & $\pm 5 \%$ & $1 \mathrm{~min}$ \\
\hline & R/V (CTD) & SBE 43 & $\pm 2 \%$ & $1 \mathrm{~s}$ \\
\hline & Glider & SBE $43 F$ & $\pm 2 \%$ & $30 \mathrm{~s}$ \\
\hline Turbidity & R/V (CTD) & WET Labs ECO FLNTU & $0.013 \mathrm{NTU}$ & $1 \mathrm{~s}$ \\
\hline PAR/irradiance & R/V (CTD) & Biospherical/LI-COR & NA & $1 \mathrm{~s}$ \\
\hline \multirow[t]{2}{*}{$\mathrm{pH}$} & Buoy (E1-M3A) & Sensor LabpH & $\pm 0.005 \mathrm{pH}$ units & $180 \mathrm{~min}$ \\
\hline & Ferrybox & Meinsberg probe & $\pm 0.3 \mathrm{pH}$ units & $1 \mathrm{~min}$ \\
\hline \multirow[t]{2}{*}{$p \mathrm{CO}_{2}$} & Ferrybox & Contros $\mathrm{CO}_{2}$ & $\pm 0.5 \%$ & $1 \mathrm{~min}$ \\
\hline & Buoy (E1-M3A) & Pro-Oceanus & $2 \mathrm{ppm}$ & $180 \min$ \\
\hline $\begin{array}{l}\text { ADCP } \\
\text { (backscattering) }\end{array}$ & Buoy (E1-M3A) & Teledyne RDI 75 kHz & $\pm 1 \%$ & $180 \min$ \\
\hline
\end{tabular}

$\mathrm{NA}=$ not available

validity of the data and a series of metadata correctness tests are applied before the release of the relevant data files. The data quality control process includes different routines for NRT products and the delayed mode/reprocessed products.

The NRT quality control consists of a set of automatic tests according to the EuroGOOS Data Management, Exchange and Quality Working Group (DATA-MEQ) recommendations (http://eurogoos.eu/data-management-exchangequality-working-group-data, last access: 26 September 2018). These procedures are defined by variable, elaborated in coherence with international agreements, in particular those adopted within SeaDataNet project (https: //www.seadatanet.org/Standards/Data-Quality-Control, last access: 26 September 2018) and they are applied by all the regional nodes of CMEMS INS TAC on the NRT products in order to assure a minimum level of quality. Detailed information on the applied procedures can be found in the CMEMS INS TAC quality control (QC) procedure manuals for temperature and salinity, currents and sea level (http://dx.doi.org/10.13155/36230, last access: 26 September 2018), waves (http://doi.org/10.13155/46607, last access: 26 September 2018), Chl- $a$ (fluorescence), dissolved oxygen and nutrients (http://doi.org/10.13155/36232, last access: 26 September 2018).

During the delayed mode/reprocessed data analysis, procedures assessing the consistency of the data over a period of time are applied to the time series. The scientific validation includes statistical tests to check the consistency of the observations and climatological tests to highlight suspicious data that could not be detected by the automatic quality control processes. The resulted outliers are reassessed through visual inspection, a procedure that has an increased level of 
Table 2. Variables measured from discrete bottle and net samples at high frequency (monthly). The method ranking is from Lorenzoni and Benway (2013).

\begin{tabular}{|c|c|c|c|c|}
\hline Variable & Platform & Analytical method & $\begin{array}{l}\text { Method } \\
\text { ranking }\end{array}$ & Accuracy \\
\hline $\begin{array}{l}\mathrm{NO}_{3}+\mathrm{NO}_{2} / \\
\mathrm{Si}(\mathrm{OH})_{4}\end{array}$ & E1-M3A, HCB & Manual spectrophotometric & Acceptable & $\begin{array}{l}<3 \% / \\
<4 \%\end{array}$ \\
\hline $\mathrm{PO}_{4}$ & E1-M3A, HCB & Magnesium-induced co-precipitation & Best & $<2 \%$ \\
\hline Total Chl- $a$ & E1-M3A, HCB & Fluorescence and HPLC & Best & NA \\
\hline Other phytopigments & E1-M3A, HCB & HPLC & Best & NA \\
\hline Viruses and bacteria & E1-M3A & Flow cytometry & Best & NA \\
\hline Picophytoplankton & E1-M3A & Flow cytometry & Best & NA \\
\hline Nanophytoplankton & E1-M3A, HCB & Microscopy (UV plus blue light excitation) & Best & NA \\
\hline Other nanoplankton & E1-M3A, HCB & Inverted microscopy & NA & NA \\
\hline Microphytoplankton & E1-M3A, HCB & Inverted microscopy & Best & NA \\
\hline Ciliates & E1-M3A & $\begin{array}{l}\text { Inverted epifluorescence microscope } \\
\text { (blue light excitation) }\end{array}$ & NA & NA \\
\hline Zooplankton & E1-M3A, HCB & $\begin{array}{l}45 \text { and } 200 \mu \mathrm{m} \text { nets, scanning and } \\
\text { image analysis }\end{array}$ & Best & NA \\
\hline
\end{tabular}

$\mathrm{NA}=$ not available

Table 3. Variables measured from discrete bottle samples at low frequency (6 to 24 months) and from sediment traps (integrating 15 days). Method ranking is from Lorenzoni and Benway (2013). + traps: measurement from both water column samples and from particulate matter in sediment traps. FB: Ferrybox.

\begin{tabular}{|c|c|c|c|c|}
\hline Variable & Platform & Analytical method & $\begin{array}{l}\text { Method } \\
\text { ranking }\end{array}$ & Accuracy \\
\hline Dis. oxygen & E1-M3A, HCB & Winkler (against CTD sensor) & Best & $<0.02 \mathrm{~mL} \mathrm{~L}^{-1}$ \\
\hline$A_{\mathrm{T}}$ & E1-M3A, FB & Potentiometric titration (closed cell) & Best & $<0.1 \%$ \\
\hline DIC & E1-M3A, FB & Coulometric determination & Best & $<0.1 \%$ \\
\hline TEP & E1-M3A & Colorimetric determination & NA & $<11 \%$ \\
\hline $\mathrm{POC} /$ & E1-M3A (+ traps) & High temperature combustion & Good & $<3.5 \% /$ \\
\hline $\mathrm{PN}$ & & via elemental analyzer & & $<2.5 \%$ \\
\hline DOC or TOC & E1-M3A & High temperature combustion & Best & $<3 \%$ \\
\hline TDN & E1-M3A & Persulfate oxidation & Good & $<5 \%$ \\
\hline DOP & E1-M3A & Persulfate oxidation & Best & $<5 \%$ \\
\hline Primary production & E1-M3A & $\begin{array}{l}{ }^{14} \mathrm{C} \text {; fractional day incubations scaled to } \\
\text { daily rates }\end{array}$ & Acceptable & NA \\
\hline Bacterial production & E1-M3A & ${ }^{3} \mathrm{H}$-labelled leucine method & Best & NA \\
\hline
\end{tabular}

$\mathrm{NA}=$ not available.

complexity on its implementation and highly relies on scientific expertise. Delayed mode/reprocessed products are available for temperature, salinity and waves, while the relevant product for Chl- $a$ (fluorescence) and dissolved oxygen is under development.

Data can be visualized through the POSEIDON website (fixed platforms, Ferrybox) and the MonGOOS data portal (http://www.mongoos.eu/data-center, last access: 26 September 2018, all platforms except sediment traps, ADCP), while the data are freely available to the public, the stakeholders and the scientific community, acknowledging the EC INSPIRE directive, in order to enable easy access to data and their reuse.

\section{Management, governance and sustainable development}

POSEIDON, and thus its subsystem of the Cretan Sea observatory, has been managed up to now at institutional level by the HCMR Operational Oceanography Unit (i.e. POSEIDON team) which is subdivided in four components, three headed by scientists (observing, forecasting/modelling, data centre) and one headed by an engineer (technical component). Within this management, the choice of infrastructure, sensors and thus BGC variables has been mainly driven by the participation in EU projects (e.g. JERICO, FixO3, JERICO-NEXT) which follow EU and international priori- 
ties. The recent emphasis given to biogeochemistry has been mainly the outcome of participation to JERICO and JERICONEXT. The latest project will allow to the Cretan Sea observatory to integrate in the nearby future new biogeochemical variables by following the recent developments in sensors observing carbonate system variables, pollutants, phytoplankton and microbial diversity, toxic algae, etc.

In the near future, the management/governance will move to a national level, as the Hellenic Integrated Marine and Inland Observing Forecasting and Offshore Technology Systems Observing and Forecasting System (HIMIOFOTS), a national research marine observing infrastructure, was initiated in 2018. Within the HIMIOFOTS network, a national management/governance is planned to be subdivided into a (i) coordination team, (ii) operational and development team, (iii) scientific/technological committee and (iv) advisory team for infrastructure users. These boards will supervise the execution of the infrastructure's strategic plan, the scientific excellence, the technological development/innovation, the long-term sustainability, the good access to the infrastructure by national and international scientists, the outreach activities and the participation in large research international infrastructure networks.

A critical issue for any observatory is its sustainability. A continuous funding which will allow not only the day-today operations but also the upgrade to the current state-ofthe-art technology is crucial. Unfortunately, in most cases, marine observatories in Europe are developed through intermittent funding and national incentives. Likewise, the fixed platform of the Cretan Sea's observatory was founded through the FP6 EU Mediterranean Forecasting System Pilot Project (MFSPP) followed by the POSEIDON project and the EFTA funds. Furthermore, some activities and developments have been funded in the framework of both EU and national projects (research and infrastructural), while in 2018 the observatory became part of the HIMIOFOTS, a research infrastructure part of the Greek research infrastructure road map.

In periods when funds are limited, it is important to have and maintain a baseline via prioritization of the variables observed and platforms used. Such a plan must take into consideration, among others, the existing historical data sets, the international priorities and efforts and the specific scientific questions in the wider area (eastern Mediterranean).

Despite some periods of low support, the multivariable, multiplatform approach and the resulting scientific production ( $>80$ peer-reviewed publications, $>170$ conference presentations, $7 \mathrm{PhD}$ theses) allowed the participation in various targeted research projects and thus the provision of funds through multiple sources. In addition, the long experience in the entire chain of operations and the particular conditions of the eastern Mediterranean make the observatory an excellent test bed both for new technology and sampling methods.

\section{Future scope, expansion and vision}

The future of the observatory is presented in a short-term strategy and a long-term vision.

1. The short-term strategy of the biogeochemical observatory follows the expansion vision of POSEIDON system which considers recommendations, guidelines and priorities defined in the national research infrastructure road map of observing systems (HIMIOFOTS), review papers (e.g. Claustre et al., 2010), EU goal directives (MSFD, H2020) and visions of European (EMB and EuroGOOS, e.g. EGMRI, 2013) and international coordinating bodies (GOOS, and Global Climate Observing System - GCOS).

A main short-term goal is attaining a NRT character for the biogeochemical variables together with a further expansion of the recorded variables, with a greater focus on air-sea interaction. Based on the key variables recommended by the EU (EGMRI, 2013), priority is currently given to further integrating sensors of $\mathrm{O}_{2}, \mathrm{CO}_{2}$, $\mathrm{pH}$ and fluorescence (Chl- $a$ ). Nutrient sensing is expected to be the next to follow, although the low concentrations found in the eastern Mediterranean constitute a strong technological challenge. HCMR plans to expand the ability to host such biogeochemical sensors (with NRT capability) to more of the existing POSEIDON platforms (e.g. buoys, Bio-Argos, gliders, drifters, Ferrybox) beyond the Cretan Sea, as done in 2017 with the addition of biogeochemical sensors to the northeast Aegean and southeast Ionian Sea buoy. In addition, a greater focus on the air-sea exchanges will be given. Finally, providing an operational status to the regular in situ sampling program is expected, following the experience gained and the standardization of the procedures.

This strategy will give scientists the opportunity to study primary production, secondary (zooplankton) production, higher trophic level web structure, as well as feedback effects, such as the capacity to store $\mathrm{CO}_{2}$, and the ecosystem's feedback on physics (light attenuation). In addition, the long-term time series data and the expanded NRT data delivery, proxy estimations, hazard mapping and higher-resolution predictions will benefit numerous society users (local authorities, technical institutions, tourism industry, educational organizations, fisheries industry, environmental organizations, policy makers, etc.).

2. The long-term vision considers further expanding the biogeochemical-ecosystem variables and spatiotemporal coverage of the observational system, including the capacity to perform deep biogeochemical observations, that will allow to resolve mechanisms that remain poorly known, like benthic-water column interactions, the functioning of mid-water and deep-water ecosys- 
tems, and the plankton vertical migration effect on active carbon flux.

Driven by other societal needs, supplementary underwater sensors will be considered. Once integrated in observing systems, these will offer scientists the potential to examine long-term effects of additional pressures (e.g. thermal regime shift, contaminants including microplastics, noise, open-ocean and deep ocean fishing, harvesting) and additional products to society (e.g. contaminant warning systems).

Data availability. All POSEIDON buoy marine data and data collected during the monthly R/V monitoring program at E1-M3A are available in the Mediterranean Sea in situ near-real-time observations product on the Copernicus Marine Environment Monitoring Service (http://marine.copernicus.eu/services-portfolio/ access-to-products/?option=com_csw\&view=details\&product_ id=INSITU_MED_NRT_OBSERVATIONS_013_035, CMEMS In Situ Thematic Assembly Centre, 2018). E1-M3A RDI ADCP data are available online (Petihakis et al., 2018). The infrastructure is continuously updated to accept and provide data from new platforms, such as gliders.

Author contributions. AK, CF, DB, DK, EK, EP, GK, GP, MN, MP, $\mathrm{NZ}, \mathrm{PP}, \mathrm{SC}$ and $\mathrm{SV}$ contributed to the data collection. AC, AK, AZ, CF, EB, EK, EP, GK, GP, GT, KT, LP, MB, MN, MR, MS, SC and $\mathrm{SV}$ contributed to the data processing. AK, CF, EP and GK prepared the figures. $\mathrm{CF}, \mathrm{EK}$ and $\mathrm{MN}$ prepared the tables. $\mathrm{AK}, \mathrm{CF}, \mathrm{EK}, \mathrm{EP}$, GK, GP, KT, LP and SC prepared the manuscript.

Competing interests. The authors declare that they have no conflict of interest.

Special issue statement. This article is part of the special issue "Coastal marine infrastructure in support of monitoring, science, and policy strategies". It is not associated with a conference.

Acknowledgements. We would like to thank Michalis Kouratoras for the infographics and all HCMR technical and scientific personnel that have contributed to discrete biogeochemical sample collection, analysis and data processing at the POSEIDON E1M3A location. Special thanks are due to the three referees and the topical editor, whose comments helped us to improve the manuscript. Part of the work has been funded by JERICO-NEXT project. This project has received funding from the European Union's Horizon 2020 research and innovation programme under grant agreement no. 654410 .

Edited by: Laurent Delauney

Reviewed by: Laurent Coppola, Vanessa Cardin, and one anonymous referee

\section{References}

Barale, V., Jaquet, J.-M., and Ndiaye, M.: Algal blooming patterns and anomalies in the Mediterranean Sea as derived from the SeaWiFS data set (1998-2003), Remote Sens. Environ., 112, 33003313, https://doi.org/10.1016/j.rse.2007.10.014, 2008.

Baretta-Bekker, J. G., Baretta, J. W., and Koch Rasmussen, E.: The microbial food web in the European Regional Seas Ecosystem Model, Netherlands J. Sea Res., 33, 363-379, https://doi.org/10.1016/0077-7579(95)90053-5, 1995.

Bethoux, J. P., Gentili, B., Morin, P., Nicolas, E., Pierre, C., and Ruiz Pino, D.: The Mediterranean Sea, as miniature ocean for climatic and environmental studies and a key of the climatic functioning of the North Atlantic, Prog. Oceanogr., 44, 131-146, 1999.

Bozzano, R., Pensieri, S., Pensieri, L., Cardin, V., Brunetti, F., Bensi, M., Petihakis, G., Tsagaraki, T. M., Ntoumas, M., Podaras, D., and Perivoliotis, L.: The M3A network of open ocean observatories in the Mediterranean Sea, in: IEEE 2013 MTS/IEEE OCEANS, Bergen, 1-10, 2013.

Cardin, V., Gačić, M., Nittis, K., Kovačević, V., and Perini, L.: Sub-inertial variability in the Cretan Sea from the M3A buoy, Ann. Geophys., 21, 89-102, https://doi.org/10.5194/angeo-2189-2003, 2003.

Cardin, V., Civitarese, G., Hainbucher, D., Bensi, M., and Rubino, A.: Thermohaline properties in the Eastern Mediterranean in the last three decades: is the basin returning to the pre-EMT situation?, Ocean Sci., 11, 53-66, https://doi.org/10.5194/os-11-532015, 2015.

Christodoulaki, S., Petihakis, G., Kanakidou, M., Mihalopoulos, N., Tsiaras, K., and Triantafyllou, G.: Atmospheric deposition in the Eastern Mediterranean. A driving force for ecosystem dynamics, J. Mar. Syst., 109-110, 78-93, https://doi.org/10.1016/j.jmarsys.2012.07.007, 2013.

Christodoulaki, S., Petihakis, G., Mihalopoulos, N., Tsiaras, K. Triantafyllou, G., and Kanakidou, M.: Human-Driven Atmospheric Deposition of $\mathrm{N}$ and $\mathrm{P}$ Controls on the East Mediterranean Marine Ecosystem, J. Atmos. Sci., 73, 1611-1619, https://doi.org/10.1175/JAS-D-15-0241.1, 2016.

Cicin-Sain, B., Balgos, M., Appiott, J., Wowk, K., and Hamon, G.: Oceans at Rio + 20: How Well Are We Doing in Meeting the Commitments from the 1992 Earth Summit and the 2002 World Summit on Sustainable Development? Summary for Decision Makers, Global Ocean Forum, $48 \mathrm{pp}$., available at: http://www.undp.org/content/ undp/en/home/librarypage/environment-energy/water_ governance/ocean_and_coastalareagovernance/oceans_at_rio_ 20howwellarewedoinginmeetingthecommitmentsfromthe1.html (last access: 26 September 2018), 2011.

Claustre, H., Antoine, D., Boehme, L., Boss, E., D’Ortenzio, F., Fanton D'Andon, O., Guinet, C., Gruber, N., Handegard, N. O., Hood, M., Johnson, K., Kortzinger, A., Lampitt, R., LeTraon, P.-Y., Le Quere, C., Lewis, M., Perry, M.-J., Platt, T., Roemmich, D., Sathyendranath, S., Send, U., Testor, P., and Yoder, J.: Guidelines towards an integrated ocean observation system for ecosystems and biogeochemical cycles, Proc. Ocean. Sustain. Ocean Obs. Inf. Soc., 1, 21-25, https://doi.org/10.5270/OceanObs09.pp.14, 2010.

Coll, M., Piroddi, C., Steenbeek, J., Kaschner, K., Ben Rais Lasram, F., Aguzzi, J., Ballesteros, E., Bianchi, C. N., Corbera, J., Dailia- 
nis, T., Danovaro, R., Estrada, M., Froglia, C., Galil, B. S., Gasol, J. M., Gertwagen, R., Gil, J., Guilhaumon, F., Kesner-Reyes, K., Kitsos, M.-S., Koukouras, A., Lampadariou, N., Laxamana, E., López-Fé de la Cuadra, C. M., Lotze, H. K., Martin, D., Mouillot, D., Oro, D., Raicevich, S., Rius-Barile, J., Saiz-Salinas, J. I., San Vicente, C., Somot, S., Templado, J., Turon, X., Vafidis, D., Villanueva, R., and Voultsiadou, E.: The Biodiversity of the Mediterranean Sea: Estimates, Patterns, and Threats, PLoS One, 5, e11842, https://doi.org/10.1371/journal.pone.0011842, 2010.

Coppola, L., Ntoumas, M., Bozzano, R., Bensi, M., Hartman, Susan, E., Charcos Llorens, M., Craig, J., Rolin, J.-F., Giovanetti, G., Cano, D., Karstensen, J., Cianca, A., Toma, D., Stasch, C., Pensieri, S., Cardin, V., Tengberg, A., Petihakis, G., and Cristini, L.: Handbook of best practices for open ocean fixed observatories, European Commission, FixO3 Project, FP7 Programme 2007-2013 under grant agreement no. 312463, European Commission, $127 \mathrm{pp}$., available at: http://hdl.handle.net/ 11329/302 (last access: 26 September 2018), 2016.

Danovaro, R. and Serresi, M.: Viral density and virus-to-bacterium ratio in deep-sea sediments of the Eastern Mediterranean, Appl. Environ. Microbiol., 66, 1857-1861, 2000.

Danovaro, R., Company, J. B., Corinaldesi, C., D’Onghia, G., Galil, B., Gambi, C., Gooday, A. J., Lampadariou, N., Luna, G. M., Morigi, C., Olu, K., Polymenakou, P., Ramirez-Llodra, E., Sabbatini, A., Sardà, F., Sibuet, M., and Tselepides, A.: Deep-Sea Biodiversity in the Mediterranean Sea: The Known, the Unknown, and the Unknowable, PLoS One, 5, e11832, https://doi.org/10.1371/journal.pone.0011832, 2010.

D'Ortenzio, F. and Ribera d'Alcalà, M.: On the trophic regimes of the Mediterranean Sea: a satellite analysis, Biogeosciences, 6, 139-148, https://doi.org/10.5194/bg-6-139-2009, 2009.

Duce, R. A., LaRoche, J., Altieri, K., Arrigo, K. R., Baker, A. R., Capone, D. G., Cornell, S., Dentener, F., Galloway, J., Ganeshram, R. S., Geider, R. J., Jickells, T., Kuypers, M. M., Langlois, R., Liss, P. S., Liu, S. M., Middelburg, J. J., Moore, C. M., Nickovic, S., Oschlies, A., Pedersen, T., Prospero, J., Schlitzer, R., Seitzinger, S., Sorensen, L. L., Uematsu, M., Ulloa, O., Voss, M., Ward, B., and Zamora, L.: Impacts of Atmospheric Anthropogenic Nitrogen on the Open Ocean, Science, 320, 893897, https://doi.org/10.1126/science.1150369, 2008.

EEA - European Environmental Agency: Priority issues in the Mediterranean environment, EEA Report 4/2006, European Environmental Agency, UNEP, Copenhagen, Denmark, 92 pp., available at: https://www.eea.europa.eu/publications/eea_report_ 2006_4 (last access: 26 September 2018), 2006.

EGMRI - Expert Group on Marine Research Infrastructures: Towards European Integrated Ocean Observation, Directorate-General for Research and Innovation, European Commission, Brussels, Belgium, 96 pp., available at: https: //publications.europa.eu/en/publication-detail/-/publication/ 8e833a62-cda0-4741-9879-8a6c58ad894f/language-en (last access: 26 September 2018), 2013.

Eker-Develi, E., Kideys, A. E., and Tugrul, S.: Role of Saharan dust on phytoplankton dynamics in the northeastern Mediterranean, Mar. Ecol. Prog. Ser., 314, 61-75, 2006.

EMB - European Marine Board: Navigating the Future IV, Position Paper 20, European Marine Board, Ostend, Belgium, 207 pp., available at: http://marineboard.eu/science-strategy-publications (last access: 26 September 2018), 2013.
Flynn, K. J.: Castles built on sand: dysfunctionality in plankton models and the inadequacy of dialogue between biologists and modellers, J. Plankton Res., 27, 1205-1210, https://doi.org/10.1093/plankt/fbi099, 2005.

Frangoulis, C., Christou, E. D., and Hecq, J. H.: Comparison of Marine Copepod Outfluxes: Nature, Rate, Fate and Role in the Carbon and Nitrogen Cycles, Adv. Mar. Biol., 47, 253-309., 2005.

Frangoulis, C., Carlotti, F., Eisenhauer, L., and Zervoudaki, S.: Converting copepod vital rates into units appropriate for biogeochemical models, Prog. Oceanogr., 84, 43-51, https://doi.org/10.1016/j.pocean.2009.09.005, 2010.

Frangoulis, C., Grigoratou, M., Zoulias, T., Hannides, C. C. S., Pantazi, M., Psarra, S., and Siokou, I.: Expanding zooplankton standing stock estimation from meso- to metazooplankton: A case study in the N. Aegean Sea (Mediterranean Sea), Cont. Shelf Res., 149, 151-161, https://doi.org/10.1016/j.csr.2016.10.004, 2016.

Galloway, J. N., Townsend, A. R., Erisman, J. W., Bekunda, M., Cai, Z., Freney, J. R., Martinelli, L. A., Seitzinger, S. P., and Sutton, M. A.: Transformation of the Nitrogen Cycle: Recent Trends, Questions, and Potential Solutions, Science, 320, 889892, https://doi.org/10.1126/science.1136674, 2008.

Georgopoulos, D., Chronis, G., Zervakis, V., Lykousis, V., Poulos, S., and Iona, A.: Hydrology and circulation in the Southern Cretan Sea during the CINCS experiment (May 1994-September 1995), Prog. Oceanogr., 46, 89-112, https://doi.org/10.1016/S0079-6611(00)00014-8, 2000.

Goffredo, S. and Dubinsky, Z. (Eds.): The Mediterranean Sea, Springer Netherlands, Dordrecht, the Netherlands, 2014.

González-Dávila, M., Santana-Casiano, J. M., Petihakis, G., Ntoumas, M., Suárez de Tangil, M., and Krasakopoulou, E.: Seasonal $\mathrm{pH}$ variability in the Saronikos Gulf: A year-study using a new photometric $\mathrm{pH}$ sensor, J. Mar. Syst., 162, 37-46, https://doi.org/10.1016/j.jmarsys.2016.03.007, 2016.

Henson, S. A., Beaulieu, C., and Lampitt, R.: Observing climate change trends in ocean biogeochemistry: when and where, Global Change Biol., 22, 1561-1571, https://doi.org/10.1111/gcb.13152, 2016.

Hoteit, I., Triantafyllou, G., and Petihakis, G.: Towards a data assimilation system for the Cretan sea ecosystem using a simplified Kalman filter, J. Mar. Syst., 45, 159-171, https://doi.org/10.1016/j.jmarsys.2003.11.003, 2004.

IMBER: Science Plan and Implementation Strategy, IGBP Report No. 52, IGBP Secretariat, Stockholm, Sweden, 76 pp., available at: http://www.igbp.net/publications/ reportsandscienceplans/reportsandscienceplans/reportno52.5. 1b8ae20512db692f2a680006730.html (last access: 26 September 2018), 2005

IMBER: Supplement to the Science Plan and Implementation Strategy, IGBP Report No. 52A, IGBP Secretariat, Stockholm, Sweden, 36 pp., available at: http://www.igbp.net/publications/ reportsandscienceplans/reportsandscienceplans/reportno52a.5. 1b8ae20512db692f2a680006711.html (last access: 26 September 2018), 2010.

Kalaroni, S., Tsiaras, K., Petihakis, G., Hoteit, I., EconomouAmilli, A., and Triantafyllou, G.: Data assimilation of depth-distributed satellite chlorophyll- $a$ in two Mediterranean contrasting sites, J. Mar. Syst., 160, 40-53, https://doi.org/10.1016/j.jmarsys.2016.03.018, 2016. 
Kanakidou, M., Mihalopoulos, N., Kindap, T., Im, U., Vrekoussis, M., Gerasopoulos, E., Dermitzaki, E., Unal, A., Koçak, M., Markakis, K., Melas, D., Kouvarakis, G., Youssef, A. F., Richter, A., Hatzianastassiou, N., Hilboll, A., Ebojie, F., Wittrock, F., von Savigny, C., Burrows, J. P., Ladstaetter-Weissenmayer, A., and Moubasher, H.: Megacities as hot spots of air pollution in the East Mediterranean, Atmos. Environ., 45, 1223-1235, https://doi.org/10.1016/j.atmosenv.2010.11.048, 2011.

Karl, D.: Oceanic Ecosystem Time-Series Programs: Ten Lessons Learned, Oceanography, 23, 104-125, https://doi.org/10.5670/oceanog.2010.27, 2010.

Korres, G., Nittis, K., Perivoliotis, L., Tsiaras, K., Papadopoulos, A., Triantafyllou, G., Hoteit, I., and Abdullah, K.: Forecasting the Aegean Sea hydrodynamics within the POSEIDON-II operational system, J. Oper. Oceanogr., 3, 37-49, https://doi.org/10.1080/1755876X.2010.11020112, 2010.

Korres, G., Papadopoulos, A., Katsafados, P., Ballas, D., Perivioliotis, L., and Nittis, K.: A 2-year intercomparison of the WAMCycle4 and the WAVEWATCH-III wave models implemented within the Mediterranean Sea, Mediterr, Mar. Sci., 12, 129-152, https://doi.org/10.12681/mms.57, 2011.

Korres, G., Ntoumas, M., Potiris, M., and Petihakis, G.: Assimilating Ferry Box data into the Aegean Sea model, J. Mar. Syst., 140, 59-72, https://doi.org/10.1016/j.jmarsys.2014.03.013, 2014.

Kouvarakis, G., Mihalopoulos, N., Tselepides, A., and Stavrakakis, S.: On the importance of atmospheric inputs of inorganic nitrogen species on the productivity of the Eastern Mediterranean Sea, Global Biogeochem. Cy., 15, 805-817, https://doi.org/10.1029/2001GB001399, 2001.

Krasakopoulou, E., Frangoulis, C., Psarra, S., Lagaria, A., Giannoudi, L., and Petihakis, G.: Carbonate system variables at the POSEIDON-E1-M3A site (S. Aegean Sea, Eastern Mediterranean), in: 11th Panhel. Symp. Oceanogr. \& Fish., 857-860, available at: https://okeanos-dspace.hcmr.gr/bitstream/handle/ 123456789/1372/PanhellSympOceanFish11(857-860)2015. .pdf?sequence $=1$ (last access: 26 September 2018), 2015.

Kress, N.: Continuing influence of the changed thermohaline circulation in the eastern Mediterranean on the distribution of dissolved oxygen and nutrients: Physical and chemical characterization of the water masses, J. Geophys. Res., 108, 8109, https://doi.org/10.1029/2002JC001397, 2003.

Laskaratos A., Roether, W., Nittis, K., and Klein, B.: Recent changes in deep water formation and spreading in the eastern Mediterranean Sea: a review, Prog. Oceanogr., 44, 5-36, https://doi.org/10.1016/S0079-6611(99)00019-1, 1999.

Lorenzoni, L. and Benway, H. M.: Report of Global intercomparability in a changing ocean: an international time-series methods workshop, 28-30 November 2012, Ocean Carbon and Biogeochemistry (OCB) Program and International Ocean Carbon Coordination Project (IOCCP), 61 pp., available at: https://www.us-ocb.org/wp-content/uploads/sites/43/2017/01/ TS_Workshop_report_FINAL.pdf (last access: 26 September 2018), 2013.

Ludwig, W., Dumont, E., Meybeck, M., and Heussner, S.: River discharges of water and nutrients to the Mediterranean and Black Sea: Major drivers for ecosystem changes during past and future decades?, Prog. Oceanogr., 80, 199-217, https://doi.org/10.1016/j.pocean.2009.02.001, 2009.
Lykousis, V., Chronis, G., Tselepides, A., Price, N., Theocharis, A., Siokou-Frangou, I., Van Wambeke, F., Danovaro, R., Stavrakakis, S., Duineveld, G., Georgopoulos, D., Ignatiades, L., Souvermezoglou, A., and Voutsinou-Taliadouri, F.: Major outputs of the recent multidisciplinary biogeochemical researches undertaken in the Aegean Sea, J. Mar. Syst., 33-34, 313-334, https://doi.org/10.1016/S0924-7963(02)00064-7, 2002.

Malanotte-Rizzoli, P., Artale, V., Borzelli-Eusebi, G. L., Brenner, S., Crise, A., Gacic, M., Kress, N., Marullo, S., Ribera D’Alcalà, M., Sofianos, S., Tanhua, T., Theocharis, A., Alvarez, M., Ashkenazy, Y., Bergamasco, A., Cardin, V., Carniel, S., Civitarese, G., D’Ortenzio, F., Font, J., Garcia-Ladona, E., Garcia-Lafuente, J. M., Gogou, A., Gregoire, M., Hainbucher, D., Kontoyannis, H., Kovacevic, V., Krasakopoulou, E., Kroskos, G., Incarbona, A., Mazzocchi, M. G., Orlic, M., Ozsoy, E., Pascual, A., Poulain, P. M., Roether, W., Rubino, A., Schroeder, K., Siokou-Frangou, I., Souvermezoglou, E., Sprovieri, M., Tintoré, J., and Triantafyllou, G.: Physical forcing and physical/biochemical variability of the Mediterranean Sea: A review of unresolved issues and directions for future research, Ocean Sci., 10, 281-322, https://doi.org/10.5194/os-10-281-2014, 2014.

Nittis, K., Tziavos, C., Thanos, I., Drakopoulos, P., Cardin, V., Gačić, M., Petihakis, G., and Basana, R.: The Mediterranean Moored Multi-sensor Array (M3A): system development and initial results, Ann. Geophys., 21, 75-87, https://doi.org/10.5194/angeo-21-75-2003, 2003.

NRC - National Research Council: Critical Infrastructure for Ocean Research and Societal Needs in 2030, National Academies Press, Washington, D.C., USA, 2011.

Papadopoulos, A., Katsafados, P., Kallos, G., and Nickovic, S.: The Weather Forecasting System for Poseidon - an Overview, J. Atmos. Ocean Sci., 8, 219-237, https://doi.org/10.1080/1023673029000003543, 2002.

Pensieri, S., Bozzano, R., Schiano, M. E., Ntoumas, M., Potiris, E., Frangoulis, C., Podaras, D., and Petihakis, G.: Methods and best practice to intercompare dissolved oxygen sensors and fluorometers/turbidimeters for oceanographic applications, Sensors (Switzerland), 16, 702, https://doi.org/10.3390/s16050702, 2016.

Perivoliotis, L., Petihakis, G., Korres, G., Ballas, D., Frangoulis, C., Paris, P., Ntoumas, M., Pettas, M., Chalkiopoulos, A., Sotiropoulou, M., Bekiari, M., Kalampokis, A., Ravdas, M., Bourma, E., Christodoulaki, S., Zacharioudaki, A., Kassis, D., Potiris, M., Triantafyllou, G., Tsiaras, K., Krasakopoulou, E., Velanas, S., and Zisis, N.: The POSEIDON system, an integrated observing infrastructure at the Eastern Mediterranean as a contribution to the European Ocean Observing System, in: 8th EuroGOOS Conference, 3-5 October 2017, Bergen, Norway, available at: http://eurogoos.eu/download/publications/ EuroGOOS-2017-Conference-Proceedings.pdf, last access: 26 September 2018.

Petihakis, G., Triantafyllou, G., Allen, I. J., Hoteit, I., and Dounas, C.: Modelling the spatial and temporal variability of the Cretan Sea ecosystem, J. Mar. Syst., 36, 173-196, https://doi.org/10.1016/S0924-7963(02)00186-0, 2002.

Petihakis, G., Drakopoulos, P., Nittis, C., Zervakis, V., Christodoulou, C., and Tziavos, C.: M3A system (20002005) - operation and maintenance, Ocean Sci., 3, 117-128, https://doi.org/10.5194/os-3-117-2007, 2007. 
Petihakis, G., Ntoumas, M., Pettas, M., Frangoulis, C., Kalampokis, A., and Potiris, E.: ADCP data from Poseidon E1-M3A observatory, Zenodo, https://doi.org/10.5281/zenodo.1311695, 2018.

Pettas, M., Frangoulis, C., and Petihakis, G.: An hydraulic winch to support deep CTD casts using small boats, in: Integrated Marine Research in the Mediterranean and the Black Sea, 7-9 December 2015, Brussels, Belgium, 323324, available at: http://www.perseus-net.eu/assets/media/PDF/ SCBrussels7-9Dec2015/6875.pdf (last access: 26 September 2018), 2015.

Pinardi, N. and Flemming, E. (Eds.): The Mediterranean Forecasting System, Science Plan, EuroGOOS Publication no. 11, Southampton Oceanography Centre, Southampton, UK, 1998.

Potiris, E., Frangoulis, C., Kalampokis, A., Ntoumas, M., Pettas, M., Petihakis, G., and Zervakis, V.: Acoustic Doppler current profiler observations of migration patterns of zooplankton in the Cretan Sea, Ocean Sci., 14, 783-800, https://doi.org/10.5194/os14-783-2018, 2018.

Psarra, S., Tselepides, A., and Ignatiades, L.: Primary productivity in the oligotrophic Cretan Sea (NE Mediterranean): seasonal and interannual variability, Prog. Oceanogr., 46, 187-204, https://doi.org/10.1016/S0079-6611(00)00018-5, 2000.

Robinson, C., Steinberg, D. K., Anderson, T. R., Arístegui, J., Carlson, C. A., Frost, J. R., Ghiglione, J.-F., Hernández-León, S., Jackson, G. A., Koppelmann, R., Quéguiner, B., Ragueneau, O., Rassoulzadegan, F., Robison, B. H., Tamburini, C., Tanaka, T., Wishner, K. F., and Zhang, J.: Mesopelagic zone ecology and biogeochemistry - a synthesis, Deep-Sea Res. Pt. II, 57, 15041518, https://doi.org/10.1016/j.dsr2.2010.02.018, 2010.

Roether, W., Klein, B., Manca, B. B., Theocharis, A., and Kioroglou, S.: Transient Eastern Mediterranean deep waters in response to the massive dense-water output of the Aegean Sea in the 1990s, Prog. Oceanogr., 74, 540-571, https://doi.org/10.1016/j.pocean.2007.03.001, 2007.

Rogers, A. D., Brierley, A., Croot, P., Cunha, M. R., Danovaro, R., Devey, C., Hoel, A.-H., Ruhl, H., Sarradin, P.-M., Trevisanut, S., van den Hove, S., Vieira, H., and Visbeck, M.: Delving Deeper: Critical challenges for 21 st century deep-sea research, edited by: Larkin, K. E., Donaldson, K., and McDonough, N., Position Paper 22 of the European Marine Board, Ostend, Belgium, 2015.

Ruhl, H. A., André, M., Beranzoli, L., Çaĝatay, M. N., Colaço, A., Cannat, M., Dañobeitia, J. J., Favali, P., Géli, L., Gillooly, M., Greinert, J., Hall, P. O. J., Huber, R., Karstensen, J., Lampitt, R. S., Larkin, K. E., Lykousis, V., Mienert, J., Miguel Miranda, J., Person, R., Priede, I. G., Puillat, I., Thomsen, L., and Waldmann, C.: Societal need for improved understanding of climate change, anthropogenic impacts, and geo-hazard warning drive development of ocean observatories in European Seas, Prog. Oceanogr., 91, 1-33, https://doi.org/10.1016/j.pocean.2011.05.001, 2011.

Saiz, E., Sabatés, A., and Gili, J.-M.: The Zooplankton, in: The Mediterranean Sea: Its history and present challenges, Springer Netherlands, Dordrecht, the Netherlands, 183-211, 2014.

Siokou, I., Zervoudaki, S., and Christou, E. D.: Mesozooplankton community distribution down to $1000 \mathrm{~m}$ along a gradient of oligotrophy in the Eastern Mediterranean Sea (Aegean Sea), J. Plankton Res., 35, 1313-1330, https://doi.org/10.1093/plankt/fbt089, 2013.

Siokou-Frangou, I., Bianchi, M., Christaki, U., Christou, E. D., Giannakourou, A., Gotsis, O., Ignatiades, L., Pagou, K., Pitta,
P., Psarra, S., Souvermezoglou, E., Van Wambeke, F., and Zervakis, V.: Carbon flow in the planktonic food web along a gradient of oligotrophy in the Aegean Sea (Mediterranean Sea), J. Mar. Syst., 33-34, 335-353, https://doi.org/10.1016/S09247963(02)00065-9, 2002.

Siokou-Frangou, I., Christaki, U., Mazzocchi, M. G., Montresor, M., Ribera d'Alcalá, M., Vaqué, D., and Zingone, A.: Plankton in the open Mediterranean Sea: a review, Biogeosciences, 7, 15431586, https://doi.org/10.5194/bg-7-1543-2010, 2010.

Sisma-Ventura, G., Yam, R., Kress, N., and Shemesh, A.: Water column distribution of stable isotopes and carbonate properties in the South-eastern Levantine basin (Eastern Mediterranean): Vertical and temporal change, J. Mar. Syst., 158, 13-25, https://doi.org/10.1016/j.jmarsys.2016.01.012, 2016.

Souvermezoglou, E. and Krasakopoulou, E.: Chemical oceanography in the Cretan Sea: Changes associated to the transient, Mediterr. Mar. Sci., 1, 91-103, https://doi.org/10.12681/mms.292, 2000.

Stavrakakis, S., Chronis, G., Tselepides, A., Heussner, S., Monaco, A., and Abassi, A.: Downward fluxes of settling particles in the deep Cretan Sea (NE Mediterranean), Prog. Oceanogr., 46, 217240, https://doi.org/10.1016/S0079-6611(00)00020-3, 2000.

Theocharis, A., Krokos, G., Velaoras, D., and Korres, G.: An Internal Mechanism Driving the Alternation of the Eastern Mediterranean Dense/Deep Water Sources, in: The Mediterranean Sea: Temporal variability and Spatial patterns, AGU Monograph Series, Washington, D.C., USA, 113-137, https://doi.org/10.1002/9781118847572, 2014.

Triantafyllou, G., Hoteit, I., and Petihakis, G.: A singular evolutive interpolated Kalman filter for efficient data assimilation in a 3D complex physical-biogeochemical model of the Cretan Sea, J. Mar. Syst., 40-41, 213-231, https://doi.org/10.1016/S09247963(03)00019-8, 2003a.

Triantafyllou, G., Korres, G., Petihakis, G., Pollani, A., and Lascaratos, A.: Assessing the phenomenology of the Cretan Sea shelf area using coupling modelling techniques, Ann. Geophys., 21, 237-250, https://doi.org/10.5194/angeo-21-237-2003, 2003b.

Triantafyllou, G., Petihakis, G., and Allen, I. J.: Assessing the performance of the Cretan Sea ecosystem model with the use of high frequency M3A buoy data set, Ann. Geophys., 21, 365-375, https://doi.org/10.5194/angeo-21-365-2003, 2003c.

Tselepides, A. and Polychronaki, T.: The CINCS Project: introduction, Prog. Oceanogr., 46, 85-88, 2000.

Tsiaras, K. P., Christodoulaki, S., Petihakis, G., Frangoulis, C., and Triantafyllou, G.: Model Simulations of a Mesocosm Experiment Investigating the Response of a Low $\mathrm{Nu}-$ trient Low Chlorophyll (LNLC) Marine Ecosystem to Atmospheric Deposition Events, Front. Mar. Sci., 4, 120, https://doi.org/10.3389/fmars.2017.00120, 2017.

Turner, J.: Zooplankton fecal pellets, marine snow phytodetritus and the ocean's biological pump, Prog. Oceanogr., 130, 205-248, https://doi.org/10.1016/j.pocean.2014.08.005, 2015.

Van Wambeke, F., Christaki, U., Bianchi, M., Psarra, S., and Tselepides, A.: Heterotrophic bacterial production in the Cretan Sea (NE Mediterranean), Prog. Oceanogr., 46, 205-216, https://doi.org/10.1016/S0079-6611(00)00019-7, 2000. 
Velaoras, D., Krokos, G., Nittis, K., and Theocharis, A.: Dense intermediate water outflow from the Cretan Sea: A salinity driven, recurrent phenomenon, connected to thermohaline circulation changes, J. Geophys. Res.-Oceans, 119, 4797-4820, https://doi.org/10.1002/2014JC009937, 2014.
Wassmann, P., Ypma, J. E., and Tselepides, A.: Vertical flux of faecal pellets and microplankton on the shelf of the oligotrophic Cretan Sea (NE Mediterranean Sea), Prog. Oceanogr., 46, 241258, https://doi.org/10.1016/S0079-6611(00)00021-5, 2000. 